NOTICE: This is the author's version of a work that was accepted for publication in Journal of World Business. Changes resulting from the publishing process, such as peer review, editing, corrections, structural formatting, and other quality control mechanisms may not be reflected in this document. Changes may have been made to this work since it was submitted for publication. A definitive version was subsequently published in Journal of World Business, Vol. 49, Issue 1 (2013). http://doi.org/10.1016/i.jwb.2013.04.005 


\title{
Business under Adverse Home Country Institutions: \\ The Case of International Sanctions against Myanmar
}

\author{
Klaus E. Meyer* \\ China Europe International Business School \\ 699 Hongfeng Road, Pudong, Shanghai 201206 CHINA \\ Telephone: +862128905647 \\ Facsimile: +862128905650 \\ kmeyer@ceibs.edu \\ and \\ Htwe Htwe Thein \\ Curtin University \\ Kent Street, Bentley WA 6102 AUSTRALIA \\ Telephone: + 61892661295 \\ Facsimile: + 61892667897 \\ V.Thein@curtin.edu.au
}

Copyright: (C) the authors, 2013

This version:

April 2, 2013

Forthcoming in:

Journal of World Business

In 2014 


\title{
Business under Adverse Home Country Institutions: The Case of International Sanctions against Myanmar
}

\begin{abstract}
We expand the institutional perspective of international business by exploring the range of institutions outside the host country that influence international business. We use a critical case, Myanmar, to explore the dynamics of institutional constraints and the reaction of business to such constraints. Our in-depth case analysis focuses on four industries for the period 1996 to 2011. On this basis, we develop the concept of 'low profile strategy' and propose a conceptual framework of home country pressures influencing multinational enterprises' international operation, and the variation of their impact across industries and firms. This framework provides a foundation for future work on the extra-territorial effects of institutions in international business.
\end{abstract}

Keywords: institutional perspective, home country environment, non-governmental organizations, foreign entry strategy, Myanmar. 


\section{Introduction}

As multinational enterprises (MNEs) operate in multiple countries they are exposed to multiple sets of institutions (Kostova, Roth \& Dacin, 2008; Peng, Wang \& Jiang, 2008). International business scholars have investigated how institutions in host economies affect MNEs entering emerging economies, notably their entry strategies (Brouthers, 1995, 2002; Meyer et al., 2009), marketing strategies (Dawar \& Chattopadhay, 2002) and human resource management practices (Ferner et al., 2001; Gooderham et al., 1999). In contrast, the role of institutions in the home country received little attention.

Home country institutions play a critical supporting role in economies at early stages of their outward foreign direct investment (FDI), as has been shown for Japan in the 1970s (Ozawa, 1979) and more recently China (Yang, et al., 2007; Luo, et al., 2010; Morck, et al. 2008; Wang, et al., 2012) and Vietnam (Nguyen et al., 2013). In particular, home country institutions shape firms' ability to access resources in their home environment and to obtain necessary regulative approvals. However, they can also create pressures on the strategies and practices in foreign countries, for example with respect to ethical business practices or standards of labor (Hartman, Shaw and Stevenson, 2003; Spar \& Yoffee, 1999). Home country institutions may even go as far as delegitimizing business in certain foreign contexts at all. Such extra-territorial effects of home institutions, however, have rarely been analysed such that we only have limited understanding how they influence international business operations.

Home country institutions influencing firms outside the country's boundaries are an increasingly important phenomenon. These pressures take all of the three forms identified by Scott (2002): regulative, normative and cognitive. Regulative pressures arise, among other sources, from legislation affecting for example exports and 
imports, tax laws, and foreign corrupt practices. Normative pressures arise from norms advocated by actors such as governmental and non-governmental organizations (NGOs), and they may be enforced through actions of stakeholders of the firm such as customers, employees, or shareholders (Christmann, 2004; Doh \& Guay, 2006; Teegen, Doh \& Vachani, 2004). Cognitive institutions arise from shared beliefs and assumption that organizations abide to without conscious analysis or thought (Zucker, 1983). They too are influenced by the media (Spar, 1998) and NGOs via public debates that shape awareness of, for example, conditions in a foreign country.

The pressure of home country institutions is particularly pertinent with respect to host countries that pursue policies that violate widely shared ethical norms. In some politically sensitive cases, international sanctions have been imposed, notably on South Africa during the apartheid regime (Kumar, Lamb \& Wokutch, 2002; van Wyk, et al., 2004), Iran during over dispute of nuclear weapons development (Carswell, 1981; Torbat, 2005), and on Myanmar during the military regime (Holliday, 2005; Martin 1012; Silverstein, 2001). In these cases, a mix of institutional pressures aimed to dissuade MNEs from engaging in the country, though there was no comprehensively enforced legal ban. Scholars of politics, law and economics have analysed the effectiveness of such sanctions in achieving their political aims (Pape, 1997; Torbat, 2005). However, to date no studies explored the reactions of firms on a more micro-level using the theoretical perspectives of international business research.

We initiate this research agenda by investigating firms in a 'critical case' (Flvybjerg, 2006), where the aforementioned range of institutions is likely to be in strong evidence: Myanmar (Thein and Pick, 2009). As emphasized by Eisenhardt (1989), a case study approach allows us to explore and understand the 'dynamics' of the phenomenon, in our study MNE operations under extreme adverse pressures. 
Specifically, it allows us first to test whether such pressures can be effective in inhibiting business at all, and second to explore how firms act under such institutional pressures where they are not overshadowed by other institutions, such as those of the host economy. Our qualitative investigation thus explores two research questions: (1) which home institutions affect doing business in or with Myanmar? (2) how do MNEs adopt their strategies to these home institutions? We are primarily interested in the second question, but the discussion above suggests that we need a solid understanding of the first question to meaningfully address the second one.

Within the case of Myanmar, we use purposeful sampling on the basis of initial research of the relevant context (Poulis, Poulis \& Plakoyannaki, 2013) to identify four sectors of industry using a $2 \times 2$ matrix structure to capture critical variations across industries in which despite international sanctions, at least some MNEs have continued or even extended their operations between 1996 and 2011. We thus distinguish market versus resource seeking and labor versus capital intensive operations. Comparisons across the four sectors provide rich foundations to explore variations in the impact of institutional pressures.

We contribute to the literature in multiple ways. First, we offer an integrative framework to analyze home country institutional pressures on businesses in a particular host country. Second, we offer a rich qualitative analysis of business in Myanmar, a context that to date received limited consideration in the international business literature. Third, we derive propositions regarding the determinants of exit and low profile strategies to guide future research. Fourth, we open research on locally relevant research questions in South East Asia that received little attention in international business research to date (Meyer, 2006; Nguyen, et al., 2013; Pananond, 2007; Tipton, 2009). 


\section{Institutional perspective of international business}

International business scholars have identified institutions as a key set of variables influencing the activities of MNEs (Peng, 2003; Peng et al., 2008). Institutions have been defined as the rules of the game and their enforcement mechanism (North, 1990). They have primarily been analysed for host economies, especially emerging ones, that constrain the operations of foreign entrants through institutional voids (Khanna \& Palepu, 1999), high transaction costs (Meyer et al. 2009), weak intellectual property rights protection (Khoury \& Peng, 2011) or high uncertainty (Delios \& Henisz, 2003; Brouthers et al. 2002). Businesses respond to adverse institutions either by staying out of the pertinent market, by adapting their organizational forms, or by building competences to deal with these particular institutional constraints (Khanna, Palepu \& Bullock, 2010). Relatedly, businesses experience differences (or 'distance') in the sets of institutions in home and host countries as a barrier that increases costs of doing business, while also creating some opportunities for institutional arbitrage (Estrin, Baghdasaryan \& Meyer, 2009; Kostova et al., 2008).

This international business literature, as well as economics literature in the tradition of North, often treats institutions as exogenous. This may be a reasonable approximation if and when analyzing small firms and short time horizons. However, institutions are at least in the long run influenced by both businesses and other institutional actors such as political parties and NGOs. For example, MNEs with substantial bargaining power vis-à-vis local stakeholders may also engage with host country governments to influence the regulative pressures pertaining to them (Hillman \& Wan, 2005; Kobrin, 1987; Kwok \& Tadasse, 2006; Nebus \& Ruffin, 2010). 
Therefore, in contrast to mainstream economic literature, the organizations literature therefore generally treats institutions as endogenous (Hoffman, 1999; Kostova, 1999).

As our study analyses a long time period and some of the businesses concerned are fairly big, we cannot maintain the assumption of exogenous institutions, and we need to incorporate the evolution of the institutions themselves in the analysis. Moreover, many of the normative and cognitive institutions pertaining to MNEs are not directly observable, but can only be identified indirectly by observing the statements of observers or institutional actors, as well as the reactions of businesses to such statements. This suggests that we need to scan broadly to identify such institutions.

Another limitation of prior research is the insufficient attention to institutions outside the country of operations. Some studies considered bilateral or supra-national institutions and agreements (Ramamurti, 2001) or the bargaining between home and host governments, and with MNEs, about the rules that apply to international business operations (Grosse, 2003; Stopford \& Strange, 1991). However, few if any studies explore a wide range of home country institutions on international business activities.

This leads us to consider how home country institutions may affect outward international business. Many countries have created institutions that support international business activities of firms from their country, especially exports or export-enhancing FDI (Ozawa, 1979; Luo et al., 2010; Nguyen et al., 2013). However, in some cases, institutions in home countries aim to constrain outward FDI, notably the practices employed by MNEs (Hartman et al., 2003). This may be motivated by hypernorms that the home society believes ought to be applied by MNEs overseas (Donaldson \& Preston, 1995), though such motivations are at times indistinguishable from protectionism when outward activities are associated with 
offshoring of operations and thus trigger political debates concerning possible job losses at home (Doh, 2005). Such institutions concern in particular labor, environment and corruption related practices and standards, and have led to widespread introduction of codes of ethics or standards of practice in MNEs (Christman, 2004; Hartman, et al., 2003; Kolk \& van Tulder, 2004; Spar \& Yoffee, 1999). In other cases, institutions delegitimize entirely doing business with certain partners or in certain territories. Such institutions are typically politically motivated and aim to penalize a country for posing a military threat or for violating basic human rights (Carswell, 1981; van Wyk et al. 2004; Holliday, 2005). In this paper, we are concerned with this latter type of institutions.

Home country institutions differ from host country institutions in that firms are 'born' into the organizational field of the home country, and hence normally do not have the option to 'opt out' of these institutions. ${ }^{1}$ In contrast, an MNE that does not want to be exposed to the institutions of a host country could withdraw or not enter (or use the threat of exit to exert pressure on local governments to change a particular regulation).

Institutions take regulative, normative and cognitive forms (Hoffman, 1999, Kostova, 1999, Scott, 2001), all of which can also influence business outside their country of origin. Regulative institutions normally apply to the territory of the regulating authority, such as a nation state. However, in some cases law makers or regulators extend the scope of their laws extraterritorially to regulate activities of their citizens or businesses elsewhere, as in the case of anti-corruption legislation in OECD countries: companies and individuals can be prosecuted in their home country for bribes paid abroad (Cuervo-Cazurra, 2008). In the special case of US 'Alien Tort

${ }^{1}$ We thank an anonymous reviewer for pointing this out. Here, 'normally' allows for the rare cases of firms moving headquarters to another country and thus escaping home institutions such as tax legislation (Meyer and Xia, 2012). 
Law', companies may even be sued in the US for violations of the, vaguely defined, 'law of nations', for example if they are deemed to be associated with organizations or governments violating human rights (Holzmeyer, 2009; Wernick, 2012). Other regulative institutions may impose tariffs, taxes, reporting requirements, or legal liabilities that create additional costs for firms operating in a foreign country.

Normative institutions establish norms on how to conduct business abroad, for example in the form of 'hypernorms' (Donaldson \& Dunfee, 1995) or minimum standards that are deemed to apply beyond national borders. This can go as far as designating a country as unfit to be a partner for business at all because of its intolerably low standards of, for example, human rights. However, norms vary and there is little international agreement beyond very abstract concepts as to what actually constitutes an internationally applicable hypernorm (Hartman et al., 2003). Hence, normative pressures affecting businesses vary dependent on where a firm originates from, and where it operates (Kourula, 2011).

Cognitive institutions guide organizations' "understanding of the nature of reality and the frames through which that meaning is developed" (Hoffman, 1999: 353). In the context of our study, they refer to cognition of corporate decision makers and customers regarding the nature of the foreign business contexts, and their perceived (not necessarily objective) linkage between business activities and undesirable practices by the host country government. Firms align to normative and cognitive pressures by developing new organizational practices or by engaging directly with the stakeholders (Frynas 2005; Oetzel \& Ketz, 2012; Sharma \& Henriques, 2005). Normative and cognitive institutions thus have been shown to affect corporate performance, at least under some conditions (Davidson, Worrel \& El Jelly, 1995; Doh, Howton, Howton \& Siegel, 2010; King \& Soule, 2007). 
Scott (2002) treats the three forms of institutions as analytically and operationally distinct, while Hirsch (1997) argues that the development of one form will influence the development of other forms. The nature of this interdependence is however disputed. For example, Hoffman (1999: 365) observed a sequence from questioning of prior organizational beliefs to regulative change, to normative change, and eventually to cognitive change. At the outset of our study we kept an open mind for the sequence of changes in institutions. For example, greater awareness of a particular human rights issue may change taken-for-granted assumptions and thus trigger a discourse that leads to normative pressures and new regulation.

Moreover, institutional change in a home country evolves under the influence of institutional actors, especially governments and NGOs. Formal institutions such as sanctions in form of for example a visa ban for key officials or outright prohibition of trade or financial transactions with a country are established by governments or legislators. In addition, NGOs are acting with the explicit aim to generate institutional pressures, including awareness (cognition) of conditions they consider undesirable, promotion of norms by which business ought to behave, and lobbying of governments to issue legislation that supports their aims (Kourula, 2011; Yaziji \& Doh, 2009). Normative pressures triggered by NGOs affect a firm's legitimacy, especially when supported by consumer boycotts or shareholder resolutions. Thus, NGO activism against firms was found to negatively influence share price performance (Davidson et al., 1995; King \& Soule, 2007; Kumar et al. 2002; Wernick, 2011), while endorsements may have a positive effect (Doh, et al., 2010).

Putting these theoretical considerations together led us to the left hand side of the initial theoretical framework for this study. In developing their strategies abroad, firms are subject to interdependent cognitive, normative and regulative pressures, 
which in turn are shaped by, among other institutional actors, governments and NGOs (Figure 1). The focal aspects of business strategy in the host country that we aim to investigate are the possible disengagement (i.e. decisions to exit the country or not to enter), and the adaptation of operational and branding strategies. Beyond these categories, we keep an open mind throughout our qualitative inquiry to identify others types of possible actions.

\section{*** Insert Figure 1 about here ***}

Firms react differently to these pressures, dependent on how sensitive they are to the afore-mentioned institutional pressures (Kourula, 2011; Rehbein, Waddock \& Graves, 2004; Teegen et al., 2004; Yaziji \& Doh, 2009). For example, a consumer goods brand may be more susceptible to divestment pressures than a business-tobusiness company. To capture a broad range of industry characteristics, we theoretically sample four industries using a $2 \times 2$ industry case design (Figure 2): First, we distinguish sectors with local market oriented from export oriented FDI; second we consider sectors with labor intensive and capital intensive FDI. As capitalintensive, we investigated the oil and gas industry (primarily resource seeking) and the telecommunications industry (primarily market seeking); while as labor intensive we investigated the garments industry (primarily resource seeking) and consumer goods industries (primarily market seeking).

For these industries, we explore the antecedents and consequences of adverse institutions originating in the investors' home countries. Specifically, we ask what pressures are firms exposed to when operating in a country under international sanctions, and how do they react to these institutional pressures?

*** Insert Figure 2 about here ***

\section{Methodology}


Starting from our initial framework (Figure 1), we aim to build theory from case analysis, specifically to identify relevant dimensions of our constructs and their interrelationships. In particular, we pursue a 'critical case analysis' (Flyvbjerg, 2006) with the aim to gain insights on how businesses deal with an extreme situation, and to incorporate such insights in a refined theoretical framework. The critical case allows us to observe the focal phenomenon, home country institutions, where they are particularly evident, and hence more tractable than in other contexts.

Myanmar 1996 to 2011 provides such a critical case subject to a variety of institutional pressures that evolved in many home countries of MNEs over a long period of time (Table 1). This allows us to gather rich data of institutions and of businesses responses to such institutions. The year 1996 marked a peak of international business following a period of market-opening, which also triggered a major wave of NGO activism against doing business in Myanmar. The years 2010/11 represent a time of gradual easing pressures culminating in US secretary of state Hillary Clinton's visit in December 2011. Over this time period, we found a high degree of persistence in the basic patterns of gradually increasing institutional pressures on businesses, yet with subtle but important variations.

$$
\text { *** Table } 1 \text { about here *** }
$$

Our analysis has been guided by the grounded theory approach which is a form of inductive theory-building (Welch, Piekkari, Plakoyiannaki \& PaavilainenMäntymäki, 2011). This approach is well-suited to circumstances where the issue to be investigated is highly complex and/or previous research in the area is scarce and, thus, hypothesis testing is premature (Strauss \& Corbin, 1990). It is thus particularly well suited to this project as it facilitates explorations of the multi-faceted impact of different types of home institutions on diverse strategic responses by businesses. Our 
data gathering, coding, analysis and theory development has been guided by Charmaz' (2006) approach to constructing grounded theory.

Given the complexity of the subject, and its political sensitivity, obtaining primary data has been a major challenge. Interviews, photographic documents and field observations were collected in several waves: 1996, 1997, 2007, 2010 and in winter 2011/2012 when the sanctions regime started to be phased out. Most interviews were conducted in Myanmar with executives (both foreign and local) working in MNEs or foreign-affiliated businesses. In addition, we also interviewed consultants and experts in Myanmar. Outside Myanmar, we held interviews via telephone, email or face to face with human rights activists, campaigners, government officials, Burmese businesspersons on overseas visits and overseas Burmese with business interests in Myanmar. Table 2 provides an overview of the interviewees. *** Table 2 about here ***

Our primary data have been complemented by a wide range of secondary data, including media articles, publications by government and non-governmental organizations, materials published by activists on websites and internet discussions, published correspondence and publications from companies active in Myanmar.

Our analysis went through six steps: In the exploratory step one, based on face-to-face interviews conducted in Myanmar in 1997 and 1998 and a review of archival data, it emerged that not all industries have been targeted equally. This initial research enabled purposeful sampling (as recommended by Poulis et al., 2013) of four industries that vary in the types of operations they might profitably conduct in Myanmar (Figure 2). Firms in these industries are subject to different types of institutional pressures, which allows us to observe and investigate a range of different reactions to institutions. 
In step two, we conducted in-depth analysis of the four industry sub-cases to identify institutions and institutional actors and business strategies (Patton 2002). Specifically, this with-in case analysis identified three themes: business opportunities from the perspective of foreign business, sensitive issues in discourses on legality and ethics in the pertinent industry, and foreign investors' home institutions involving cognitive, normative and regulative aspects. Table 3 was developed during step two.

$$
\text { *** Insert Table } 3 \text { about here *** }
$$

In step three, we did a cross-case analysis using a constant comparison approach to compare themes that emerged from different groups so as to fine-tune emergent propositions (Charmaz, 2006). In each industry, we thus identified institutions and institutional actors and how they impact on business, as summarized below. Moreover, we extracted quotes from the qualitative data that characterize the observed strategies adopted by international business that either stayed or left the country (Table 4).

$$
\text { *** Insert Table } 4 \text { about here *** }
$$

In step four, we aimed to enrich the initial framework by refining each component. We achieve this aim by supplementing and/or validating the secondary data with fieldwork observations, photographic documentations and face to face interviews and interviews by emails. In step five, the aim has been to make explicit some of the pivotal relationships in the model by expressing them in testable propositions.

\section{Context: Institutions and International Business in Myanmar}

As the national and international context of our study is central to the investigation, we first introduce the context and the institutions relevant in this empirical field. Following political and economic upheaval and the repression of dissidents in 1988, 
the State Law and Order Restoration Council (SLORC) took control of Myanmar, ending 24 years of socialist government. However, the failure of the military regime to restore democracy, in addition to alleged narcotics production and labor rights violations, have shaped Myanmar's external economic relations for almost two decades (Table 1). The US imposed sanctions against Myanmar in 1997 that were gradually intensified over the next two decades amid pressures by human rights and pro-democracy campaigners (Martin, 2012). Specifically, 'new investments' by US citizens and companies in Myanmar were prohibited. In 2003, following another crackdown on political dissidents, the US government stepped up its sanctions with the Burma Freedom and Democracy Act which, among other measures, banned all imports from Myanmar to the US, with the exception of teak and gems processed outside Myanmar. In 2008, the Tom Lantos Block Burmese Jade Act banned the importation of jadeite and rubies mined in Myanmar (Martin, 2012).

Meanwhile, the EU in 1996 imposed a range of restrictions including a visa ban on top-ranking officials in the military regime and their family members, an arms embargo, and deferment of senior-level governmental visits to Myanmar (European Union, 1996). Following the oppression of protesters during the monks-led, nationwide demonstrations in 2007, the EU extended restrictions to include a ban on exports of Myanmar timber, metals and precious stones into the EU (Vogel 2009).

These sanctions developed in the interplay of several institutional actors, including NGOs and national governments. For example, human rights groups campaigned for further trade sanctions in response to reports of severe human rights abuses (Oil and Gas Journal, 1997), while international consumer boycotts, or the threat of them, organized by Burma campaign groups reportedly led to the withdrawal of many companies (Bray 2002). Likewise, social investors demanded that companies 
make 'ethical' investment decisions, and advocated shareholder resolutions for companies investing in Myanmar to develop guidelines about their policies there (Fulman 1997). At the supra-national level, the United Nations and the International Labor Organization (ILO) criticized Myanmar for the exploitation of forced labor and the perpetuation of human rights abuses (Silverstein, 2001).

In contrast, the Association of South East Asian Nations (ASEAN) adopted a policy of economic and political 'engagement', arguing that this would be more effective in facilitating steady, stable and gradual change (Silverstein, 2001). Thus, ASEAN admitted Myanmar as member in 1997, and, in 2011, agreed that the country would assume the chair of ASEAN in 2014. Likewise, Asian countries such as China, Japan and Korea experienced few if any substantive adverse institutional pressures on businesses operating in Myanmar. The rise of regional MNEs from, for example, China and Thailand since 2005 (Deng, 2009, Meyer and Thaijongrak, 2013, Pananond, 2007) thus increased the diversity of pressures on potential foreign investors.

\section{Business Responses to International Institutional Pressures}

To analyse the impact of adverse institutional pressures, we investigate four industries

(Figure 2) with respect to a) relevant home institutions and b) business adaptations to such institutions.

\section{Resource seeking/capital intensive: oil and gas exploration}

In the oil and gas industry, Myanmar offers significant business opportunities to exploit natural resource deposits and to construct related infrastructure, such as ports and pipelines. Projects typically share several characteristics: (a) they are capital intensive, (b) they have long pay back periods from the start of construction to the generation of net revenues, (c) they involve close government interfaces due to the 
need for licenses and permits, and (d) they require complementary capabilities from multiple companies (Asmus and Persechino, 1998, Frynas, 2005). In consequence, major projects are typically organized as consortia involving technology providers, construction firms, downstream future users of the resources, and local partners. In Myanmar during the period of our investigation, the participation of a local partner was mandatory, most frequently the state-owned Myanmar Oil and Gas Enterprise (MOGE), and/or the military's commercial arm, the Union of Myanmar Economic Holdings Company (UMEH).

Institutions. Foreign investors in extractive industries have been heavily criticized by a variety of NGOs including trade unions, environmental activists (Casey, 2007), and pro-democracy groups (Oil and Gas Journal 1995; 2000; Reh, 2005)). Their actions created direct and indirect pressures through all three forms of institutions. Cognitive pressures were created by raising public awareness in the US and Europe of (1) the general conditions in Myanmar, (2) the activities by MNEs in the country and (3) the supposed linkage between the two. For example, human rights activists publicized reports suggesting that investment in the oil and gas sector supported the military junta and damaged the environment in Myanmar, singling out the two Western MNEs operating in Myanmar since before 1997. Unocal, which partnered with MOGE in a US\$1.2 billion project to pipe natural gas from Myanmar to Thailand, was accused of using 'slave' labor and being implicated in human rights abuses in the context of this pipeline consortium (Oil and Gas Journal, 2000; Holzmeyer, 2009). Likewise, French oil company Total attracted criticism for its investment in the Yadana pipeline project (Voice of America, 2009).

Initially, such awareness campaigns made some consumers and politicians cognizant of the pertinent issues and triggered debate in civil society, especially in the 
US and the UK, thus undermining existing assumptions, i.e. cognitive institutions, on business in Myanmar. Norms promoted by NGOs with respect to "international" standards for labor, environment and human rights were gradually adopted by stakeholders, including shareholders. This led to normative pressures, which in some cases were reinforced by normative statements from home governments. For instance, in 2000, the British government requested Premier Oil Plc to withdraw from Myanmar (Oil and Gas Journal, 2000). Likewise, the French government has, from time to time, appealed to Total to review their investment in Myanmar.

The normative pressures also influenced politicians in US. Under pressure "to take action", they initiated regulative pressures such as the executive order prohibiting US companies from undertaking new investments in Myanmar. Of particular relevance to this sector in the US has also been Section 1504 of the Dodd-Frank Wall St. Reform Act in 2010, which required companies listed on US stock exchanges to reveal their financial contributions to host governments (Lugar and Cardin, 2010). In addition, NGOs used the court system to trigger regulative pressure. A civil suit in the USA under the Alien Torts Act against Unocal for its alleged complicity in human rights abuses by the Myanmar regime was settled in 2004 (Holzmeyer, 2009).

Business Reactions. US companies responded to the normative pressures, even in the absence of regulative requirements for a complete withdrawal. The initial sanctions by the US government in 1997 only prohibited US companies from committing "further" investment in Myanmar. Hence, US companies like Unocal/Chevron and Catarpillar were permitted to retain their existing operations as "status quo". However, ARCO, an oil and gas company, pulled out of Myanmar when threatened by the possibility of a shareholder resolution, which itself arose from normative pressures supported by a call for boycott by the Free Burma Coalition, an 
activist NGO. ARCO had invested over US\$55 million, but did not renew its lease to explore gas in the Gulf of Martaban (Oil and Gas Journal, 2000). ARCO quoted lower than expected finds for its decision, but pressures on US businesses to stop dealing with the junta also appear to have influenced that decision (Energy Economist, 1998). Also, Amoco and Texaco pulled out of Myanmar as a result of divestment resolutions by shareholders (Global Investor, 1995).

While NGOs claimed credit for such withdrawals, this view has not been shared by local observers who pointed to the lack of profitable finds [Table 4, quote A-out1]. Moreover, for other oil and gas businesses, it has been 'business as usual'. Companies from across Asia such as CNPC (China), Petronas (Malaysia), Nippon Oil (Japan), Daewoo (South Korea), Gail India, and Oil and Natural Gas (India) entered agreements with the government of Myanmar to explore and/or buy energy resources (The Australian, 2007; Quotes A-in1 and A-in2). Thus, withdrawals in this sector appear limited to a small number of cases that were still at early stages of exploration.

\section{Resource seeking/capital non-intensive: Garment Manufacturing}

The main business opportunities for the garment industry lay in export oriented businesses that exploit local inexpensive low-skilled labor based on relatively small capital investments. In consequence, sourcing decisions were far more flexible. Until 2001, this industry experienced rapid growth in Myanmar, albeit from a very low base. However, the price competitiveness of the industry and Myanmar's lack of unique resources placed the industry in a weaker negotiation position than the natural resource industry.

The leading business model of this industry involved offshore outsourcing (Doh 2005). Thus, brand name companies in Europe or North America would contract local companies to manufacture garments for them. However, the 'local' companies 
are not necessarily domestically-owned: Companies from for example Korea, Hong Kong and Taiwan specialize in managing labor intensive manufacturing processes, and own plants in places like China, Vietnam or Myanmar.

Institutions. Consumer groups in the US, and to a lesser extent in the EU, amplified calls for a boycott of products from Myanmar around the year 2001. Their activities increased consumer awareness of the situation in Myanmar and created normative pressures on trade intermediaries to discontinue sourcing from Myanmar (Kudo, 2005). Formal restrictions were created in the USA with the Burma Freedom and Democracy Act in 2003, which banned the import into the USA of garments manufactured in Myanmar. The acceleration of different levels of pressure thus evolved highly interdependently [Table 4, quote B-out1].

Another multilateral institution, perhaps paradoxically, encouraged sourcing garments from Myanmar, namely the multi-fibre-agreement (MFA). In the early 2000s, countries like China and Vietnam hit their limits under the MFA quotas, which led to trade diversion effects benefitting Myanmar. The MFA expired in 2005 and with it its unintended trade diversion.

Business Reactions. These institutional pressures emanating outside the country had a strong impact on the garments industry. Especially Western clothing labels discontinued sourcing arrangements, which resulted in a decline of garment exports from Myanmar from estimated US\$ 327 million in 2003/04 to US\$ 216 million in $2004 / 05$, with exports to the USA falling by 50\%. Especially small firms closed down, while foreign-owned businesses and those closely associated with the military continued to export (Kudo, 2005). The closures of garment factories resulted in job losses by factory workers, especially women, many of whom were migrant workers from rural areas [Table 4, quotes B-out2 \& 3]. 
International garment labels that had outsourced manufacturing to Myanmar could easily terminate their activities in the country. In contrast, plant owners had sunk investment and could not as easily walk away. Especially for small businesses from neighbouring countries, writing off their investment was neither economically viable nor politically mandated [Table 4, quote B-in5]. One of their survival strategies included circumventing the ban by exporting via intermediate destinations. For example, it appears to have been common practice to sew in 'Made in Thailand' labels on garments made in Myanmar but finished in Thailand [Table 4, quote B-in1]. However, such strategies put pressures on the profitability of manufacturers in Myanmar because of reduced demand for 'Made in Myanmar' and intermediaries taking their commission [Table 4, quote B-in2].

In the garments industry thus, home country norms influenced purchasing behaviors of key intermediaries, which led to falling garments exports, even before they were formally banned. Cognitive consumer awareness and normative pressures preceded the introduction of formal regulations, that themselves were an outcome of the normative pressures. With plenty of other locations offering inexpensive lowskilled labor, importers in Europe and the US switched to alternative suppliers especially after the expiry of the MFA. In contrast, countries like Korea or Japan with less consumer concern about human rights, continued to import garments from Myanmar [Table 4, quote B-in3].

To sum up, the garments industry showed a stronger and more diverse business response than the oil and gas industry. There were more exits, especially by US buyers, and considerable downscaling of the industry. Notably, international garment labels reacted to normative pressures by discontinuation of sourcing from Myanmar even before new regulations came into force. At the same time, the plant 
owners who had invested in machinery with substantial sunk costs found new markets both inside and outside Myanmar.

\section{Market seeking/capital intensive: Telecommunications}

Telecommunications offered great market potential in terms of unmet demand for services and infrastructure in Myanmar. However, international investment projects in this sector are often capital-intensive and involve substantial knowledge transfer, and they occur in a context of extensive host government regulation. During our study period, the country was considered to employ one of the most restrictive regimes in the world in terms of censoring and policing internet usage (Parker \& Sam, 2005). Consequently, telecommunications remained relatively underdeveloped and under the direct control of a Myanmar government monopoly [Table 4, quote C-out1]. Only 1 in 50 citizens had a phone line (fixed or mobile phones), while due to restricted access and high monthly fees, Myanmar ranked among the lowest in the world in terms of internet users (rank 158 of 216) (CIA, 2012).

Institutions. The telecom industry was exposed to diffuse pressures because of conflicting impacts of their presence in Myanmar. On the one hand, telecom companies were implicated in the restrictions on freedom of speech and access to information imposed by the government. In 2005, Reporters Sans Frontières rated Myanmar as the country with the least free press in East Asia, due to the junta's imprisonment of pro-democracy journalists and censorship of the press (The Irrawaddy 2005b). On the other hand, the internet and mobile phones in Myanmar played a pivotal role in distributing news and images of the September 2007 protests and the subsequent government crackdown, with protesters instantaneously transmitting images and text messages around the world. The effectiveness of these 
communications resulted in the government temporarily shutting down all internet and phone services at the peak of the protests (Elmore, 2007).

In consequence, the pressures on telecom companies have been controversial even among activists and NGOs. On the one hand, the government's tight control and involvement of government officials and their family members provided basis for normative pressures not to invest in Myanmar. On the other hand, the telecom development arguably helped interconnectivity and, hence, the political opposition.

Business Responses. Given a strictly controlled and protected nature of the telecom industry in Myanmar, during our study period only a few foreign businesses operated in the sector, except in selling equipment [Table 4, quote C-in3]. The expansion of the Burmese telecom network has been led by two Chinese companies ZTE and Alcatel Shanghai Bell (ASB), a joint venture between Alcatel-Lucent and Shanghai Bell, who constructed telecom towers in Yangon and Mandalay (Moe, 2008). New Zealand's state-owned telecom company, Kordia was another partner in these projects. This led to pressures by activists and opposition parties on the New Zealand government. The then prime minister of New Zealand defended Kordia's involvement with four arguments: 1 . New Zealand currently does not have formal sanctions on Myanmar, 2. The project was a joint-venture with a Thai company (ALT Inter Corporation), 3. The project involved a relatively small amount of investment (US\$ 62,400), and 4. Helping the telecom sector to expand was "an aid to democracy" in that it facilitated information flows in and out of the country, pointing to the September 2007 protests as evidence that image protests were transmitted to the outside world aided by telecom technology (The Irrawaddy, 2008).

In March 2010, a French television documentary alleged that French telecom giant Alcatel-Lucent was helping the military government to build infrastructure that 
would allow it to police emails and filter other internet-based communications.

Alcatel Lucent was involved via its Chinese joint venture ASB [Table 4, quote C-in1]. In a press release, Alcatel Lucent denied providing devices for monitoring calls or filtering the Internet, emphasizing instead that ASB had been involved in a Chinese government funded project to improve the telecom infrastructure of Myanmar. The project involved the establishment of a GSM mobile phone network to which ASB contributed physical infrastructure. Alcatel Lucent also expressed "concern" about the political situation, arguing "that improving the communications infrastructure of a country largely benefits the people of that country, by supporting the population's economic and cultural well-being and ultimately its capacity to evolve to democracy" (Alcatel Lucent, 2010).

While Chinese telecom companies operated in Myanmar as business as usual [Table 4, quote C-in2], Western companies kept a low profile. NGOs thus directed their attention to telecom companies with only small and indirect investments, or that were only engaged via selling of telecom equipment [Table 4, quote $\mathrm{C}$-in3]. The main response from Western investors has been to engage with critical stakeholders, but not to downscale or withdraw from projects. On the other hand, they did not increase their investment commitments either.

\section{Market seeking/capital non-intensive: Branded consumer goods}

The local market in Myanmar opened to international consumer brands with economic liberalization in 1988, though demand remained low due to the low level of income. Foreign consumer brands could reach the Myanmar market via imports from third countries with or without a local operation or a direct sales relationship. Throughout the period of sanctions, many consumer brands from all over the world 
were openly sold in Myanmar, including brands from countries with sanctions and/or active consumer boycott campaigns.

Institutions. The institutional pressures on branded consumer goods manufacturers originated in both their respective home countries and Myanmar itself. In Myanmar, restrictions and inconsistent regulation of the import of luxury goods created market imperfections that encouraged grey markets and informal border trade. Internationally, cognitive awareness and norms evolving under the influence of activists created pressures on MNEs to withdraw from Myanmar as a gesture of support to opposition movements (Bray 2002). For example, Burma Campaign UK argued that foreign investment would prolong the reign of the military regime and annually published, up until 2008, a "dirty list" with the names of companies active in Myanmar, arguing that such businesses contributed to funding or supporting the regime directly or indirectly.

These normative pressures in the consumer goods sector have been reinforced by activist shareholders, boycott action groups and political initiatives such as the proposed, but never implemented, 'selective purchasing' law proposed in the State of Massachusetts. These pressures affected specifically US businesses because Asian and, to a certain extent European, counterparts faced fewer, if any, pressures not to sell their products in the country.

Business Responses. Many Western consumer brands have been present in Myanmar through non-equity activities, relying on local small and mediumsized enterprises or independent Thai or Indian owned companies as their local distributors or representatives. Some of these companies pulled out of Myanmar even before US sanctions were imposed in 1997, highlighting the effectiveness of normative pressures. Others delayed their entry or had no local presence before 
the end of sanctions in 2012. However, our interviews suggest that not all 'departing' companies withdrew their products completely.

In spite of publicly declared intent to divest from Myanmar, some companies 'downsized' their local operations but maintained some form of local presence. Their brands continued to be widely available based on creative strategies that brought the brand to local consumers while, at the same time, limiting its exposure to foreign visitors and media (Reid et al., 2001; Thein, 2003). For example, many withdrew expatriates and transferred their responsibilities to less visible local staff [Table 4, quote D-in1]. Others disguised their links to Myanmar by using independent distributors, or to 'leave' exporting to border traders and smugglers [Table 4, quote D-in7]. However, it is difficult to distinguish between deliberate intent to obscure the link and the smugglers acting on their own accord.

In the country itself, foreign brands kept a low visibility. In 1996/97, outdoor posters and banners around Yangon prominently displayed U.S. brands, especially for cosmetics and clothing, and ran ads on local TV stations. ${ }^{2}$ However, by 2007, they avoided big cities, and concentrated on country towns, where they could afford to be more visible [Table 4, quotes D-in2 \& D-in3]. Outdoor advertising peaked around the mid-1990s but was drastically reduced following divestment pressures [Table 4, quote D-in6]. Some executives referred to billboard advertising in Myanmar as being the 'worst' advertising tool because they provided the most visible and uncontrolled exposure of the advertized brand, and were thus particularly unhelpful for MNEs that hoped to keep their presence in Myanmar 'under wraps'. Compared to billboards, television was believed to be a 'safer' medium [Table 4, quotes D-in4 \& 5]. Others

2 The second author collected photographic evidence herself and from secondary sources, and recorded advertisements on Myanmar television on VCR. 
used less visible promotion tools such as face-to-face demonstrations and product giveaways, as opposed to more 'exposed' conventional advertising.

Hence, sanctions did not prevent the distribution of international brands in Myanmar. Rather, brand principals pursued a variety of low profile strategies that reduced local presence in terms of investment and public visibility, but still made products available locally.

\section{Conceptual Development}

A number of common themes arise from the analysis of our four industry cases. First, the three forms of institutions (Scott, 2002) are constantly in flux, their changes evolve interdependently, and they complement each other in creating pressures on businesses operating in Myanmar. The interdependence we observed appears to run from changes in cognitive institutions due to changes in the awareness of events in the country and how they may be related to MNEs operating in the country. These cognitive changes are the foundation for the development of normative pressures firstly directly on business (for example via consumer boycotts or shareholder resolutions) and secondly on governments and law makers that may respond changing regulative institutions [see Table 4 , quotes B-out3 \& C-in1].

Second, we observed a variety of strategic responses that fall between the polar categories of 'business as usual/entry' and 'exit/non-entry', such as low commitment entry modes and organizational structures (Table 4, quote D-out1 \& Din7), low profile branding, advertising and promotion (Table 4, quotes D-in4, $5 \& 6$ ), or serving the market indirectly via partners in a neighbouring country (Table 4, quote D-in8). These observations lead us to propose the concept of 'low profile strategy', defined as a strategy that reduces visibility and commitment but continues a presence in a given market, which we discuss further below. 
Third, while the institutional pressures are quite similar across industries (see Table 3), business responses vary across industries. As we will discuss below, some of these variations follow the industry distinctions we used to structure our analysis (local market versus export orientation, capital-intensive versus non-capitalintensive), while other variations follow other patterns, as we discuss below.

Based on these three observations, we have revisited our initial framework (Figure 1) to refine the concepts and relationships and developed a more detailed conceptual framework of business in a country under international sanctions (Figure 3). In the following, we explore some of these concepts and relationships in more detail, and offer testable propositions.

$$
\text { *** Insert Figure } 3 \text { about here *** }
$$

\section{Low Profile Strategies}

Our data suggest that many of the strategies by firms active in Myanmar between 1997 and 2011 can be characterized as 'low profile strategies' (Table 5). We find MNEs' propensity to develop such strategies to vary across firms and industries, specifically their sensitivity and responsiveness of a firm to institutions, which in turn is associated with (1) reputation risk, (2) the size of the business opportunity and (3) the non-recoverable investments that would have to be written-off in case of an exit.

These strategies are designed not only to comply with (regulative) sanctions, but to stay out of the 'spotlight' (Spar, 1998) of the media. Like the use of more independent entry modes in countries of high political risk (Brouthers, 1995), low profile strategies are used to reduce the exposure to risk. With respect to home institutions, they reduce the risk of attracting negative publicity and hence of a consumer boycott in the home country. For example, 'indirect' operation modes such as distributors based locally or in third countries (as opposed to own operations in 
Myanmar) enable brand principals to comply with home country legal requirements while creating a perceived distance between the brand and the county under sanctions, [Table 5, quote Indirect-1 to 3]. Others manage their operations via their Singapore or Bangkok office rather than communicating directly with their Myanmar operation [Table 5, quote Reduce-1 \& 2]. Moreover, foreign consumer brands were often promoted in Myanmar via local promotions rather than more visible advertising billboards [Table 5, quote Promotion-1 to 5]. Thus, adverse home institutions triggered a wide range of unorthodox market entry and promotion strategies, which we call low profile strategies:

Proposition 1: In a sanctioned country, MNEs employ a wide variety of 'low profile' strategies that reduce visibility and commitment without complete discontinuation of operations.

\section{Reputation Risk}

A key concern motivating low profile strategies has been corporate reputation, a critical and potentially valuable aspect of branding (Fombrun \& Shanley, 1999, Mahon, 2002). Reputation is, however, fragile in the sense that it can be damaged by actions considered unethical by key stakeholders. Reputation risk refers to the possible financial loss that a firm may suffer when its brand reputation is negatively affected. When designing their strategies, firms are conscientious of this risk, and perhaps for this reason high reputation companies have been found to stay out of least developed countries (Musteen, Rhyne \& Zheng, 2012) and conflict zones (Driffield, Jones \& Crotty, 2013). Such risk for corporate reputation is a major concern when it comes to engaging with a country that is de-legitimized by institutions in the firm's home country. Thus, many US and European companies pulled out of the Myanmar market without being legally required to do so, because of concerns that association with an 
international 'pariah' such as Myanmar could tarnish their corporate image:

Proposition 2: In a sanctioned country, MNEs with higher reputation risk are more

likely to exit, or to pursue low profile strategies.

Reputation risk varies across industries. In the market seeking/labor-intensive sector (consumer goods) we observed companies being concerned that their brands may be negatively affected. Export-oriented/labor intensive businesses (garment manufacturing) reduced sourcing from Myanmar because consumers reject the products themselves because of the "Made in Myanmar" association (Table 4, quotes B-out 1 to 4). In contrast, resource seeking/capital intensive businesses in the oil and gas sector continued depite of adverse pressures, while withdrawals appeared to be mostly caused by technical difficulties and unprofitable finds (Table 4, quote A-out1).

Hence, we observe greater sensitivity to normative institutions in sectors where consumers can make a direct connection between the product or brand they buy and the firms' activity in Myanmar. Among resource-seeking firms, this had a stronger effect on garments because the physical label 'Made in Myanmar' would create a cognitive linkage to the country, whereas oil and gas was sold relatively anonymously via wholesale markets.

For market-seeking firms, the linkage was created by NGOs publishing lists of firms active in Myanmar, which premium brands especially saw as a threat to their reputation. For example, Pepsi Co withdrew from Myanmar following boycott calls in the US [Table 4, quote D-out1]. In this case, activists succeeded in raising cognitive awareness of consumers and other stakeholders, which led to normative pressures on businesses to withdraw from Myanmar. Reputation risk thus is subject to consumers' cognitive beliefs, which may trigger a boycott of a brand or company. If a valuable 
reputation is at stake, such pressures may lead to a decision to cease operating in a targeted country, even without legal prohibition (Table 4, quotes D out-2 \& 3). Hence, Proposition 3a: The reputation risk that may induce firms to pursue low profile strategies or to exit is positively associated with a) products that fully or in part originate from the sanctioned country, b) brands that are associated with business in the sanctioned country.

Reputation risk also depends on characteristics of the firm itself (Godfrey, Merrill \& Hansen, 2009) and its stakeholders. In particular, it increases with the size of the firm as bigger companies are more likely to be targeted by activists (Rehbein et al, 2004). For instance, Burma Campaign UK launched special campaigns focusing on large companies in for example oil and gas (Total), insurance (Lloyd of London) and tourism (Lonely Planet). Large firms even faced pressures when their link to Myanmar was only indirect, for instance as joint venture partners or as up- and downstream customers and suppliers. For instance, one report targeted companies that provided insurance services to companies operating in Myanmar or that had offshore partners that in turn subcontracted work to Myanmar (Burma Campaign UK, 2008). Larger firms with complex supplier relations and/or geographically dispersed subsidiaries are thus at greater risk of adverse home institutional pressures. Hence, reputation risk emerges from our data as driven by firm characteristics, such as its size:

Proposition 3b: The reputation risk that may induce firms to pursue low profile strategies or to exit is positively associated with the size of the firm itself.

Reputation risk is also related to a brand's country of origin. While North American and European enterprises appeared somewhat cautious, Asian businesses (in particular, from China, Thailand, Korea, Taiwan, Singapore and Malaysia) have developed thriving investment and trade relationships. In particular, in the resourceseeking industries (garments, as well as oil and gas), all direct investment came from Asian firms. By the late 2000s, Chevron and Total were the only remaining major 
Western businesses in the oil and gas industry, while, new investors from a range of Asian nations were competing to build relationships with the government to access Myanmar's offshore gas deposits and other energy sources [Table 4, quote A-in1].

In the market-seeking/capital non-intensive sector, many Asian brands were marketed in a business-as-usual manner whilst Western-brands were promoted via low profile strategies to avoid unwanted attention from journalists and human rights activists in their home countries or key markets [e.g. Table 4, quote D-in9]. Western brands thus had to negotiate conflicting pressures between exposure to Western visitors in Myanmar, and local consumers seeking consumer goods of higher quality.

The underlying institutional issue is that Asian firms face less risk to their reputation by their association with Myanmar compared to Western businesses, because in Western countries norms evolved to penalize businesses dealing with Myanmar in part because their consumers were less aware of the specific political situation, and in part their home country society had less missionary zeal trying to change other countries. As a result, Asian firms were more active in Myanmar in a business-as-usual mode, whilst those from the US and the EU operate with more restricted modes (Table 4, quotes B-in5, D-in 9):

Proposition 3c: The reputation risk that may induce firms to pursue low profile strategies or to exit is positively associated with a) the cognitive awareness in the home country of conditions in the sanctioned country, and b) with the normative pressures to transfer the home country's norms to the host country.

\section{Business Opportunity}

The second set of influences relates to the size of business opportunity in the country, relative to alternative opportunities. In market-seeking sectors, many MNEs operating in Myanmar sought early mover advantages in building reputation with local consumers and stakeholders while being somewhat protected from competition. Such early mover advantages included brand awareness, large initial market share, local 
network contacts and, in some cases, long-term contracts with the Myanmar government. Notably, in the consumer goods sector, where brand awareness is a key advantage, early entering brands from Japan (such as Toyota, Toshiba, Sony, Konica, Kanebo) and Korea (such as Samsung, Daewoo, Kose) were well established with Myanmar consumers, creating major challenges for Western brands that made their entry (or re-entry) after 2011 [Table 4, quote A-in2]. Early movers expected the value of first mover advantages to exceed the downside of not being aligned with the sanctions regime.

In resource seeking sectors, the availability of alternatives for scarce resources determined the size of the business opportunity. This explains the differences between the garments and the oil and gas sectors: Garments can be manufactured at many places around the world, while natural resource deposits are scarce. Hence, natural resource businesses have fewer alternative investment opportunities, which explains their keen interest in Myanmar. Some energy firms have defied pressures from home institutions to retain their access to scarce resources, such as gas fields (Table 4, quotes A-in2 \& 3), while garment firms were much more responsive to calls for market exit, largely by working with alternative suppliers in other nations (Table 4, quotes B-out2, 3 \& 4). Hence, Proposition 4: In a sanctioned country, MNEs are less likely to exit, and more likely to pursue low profile strategies, when they perceive relatively unique business opportunities arising from a) first mover advantages in local markets, or b) local resources that are scarce and not easily substitutable from other sources.

\section{Non-recoverable Investments}

A third factor determining the actions of firms already present in the country are the non-recoverable investments that would have to be written off in case of an exit. For example, Chevron/Unocal and Caterpillar were present in Myanmar before the prohibition of new investment in 1997. They were permitted to continue operating as 
they were 'grandfathered' into the Myanmar sanctions regime introduced in 1997 (Interviewee Z23, 2012), yet faced normative pressures. However, they had already made substantial commitment, especially when they had entered legally binding longterm contracts with partners in a consortium. These investments generated cash flow despite the sanctions. Yet, due to financial sanctions prohibiting transactions involving Myanmar, few, if any, Western buyers would be willing to buy the assets at 'normal market values' (Table 4, quote A-in3). The sale of such assets, for example oil exploration sites, would thus involve a substantive write-off because markets for assets in Myanmar were depressed during the sanctions as US and EU bidders were not permitted to buy such assets (Table 4, quote A-in3). Selling such assets, to local firms at a depressed price would, however, hand over assets to the military regime and, hence, create effects contrary to the purpose of the sanctions. Asian buyers would have been willing to fill in the vacuum, but such a replacement would not achieve the underlying intentions of disrupting the economy of the sanctioned economy.

This issue has been most relevant in capital-intensive industries such as oil \& gas and telecommunications where exit costs are high due to large investment and potential contingent liabilities from contracts. Exit costs are lower in labor-intensive sectors such as garment manufacturing where fixed investments are small (Table 4, quote B-out4). Hence:

Proposition 5: In a sanctioned country, MNEs are less likely to exist, and more likely to pursue low profile strategies, the higher the non-recoverable investments they previously incurred.

\section{Discussion}

We have explored the complex network of institutional pressures in MNEs' home countries that de-legitimize engaging in business with a particular country. Benefiting rich qualitative data gathered in Myanmar through interviews, site visits and 
observations for over many years, our analysis focused on the adaptations of businesses, not only in terms of possible divestment - the most radical response - but the more fine-grained strategies that firms develop to handle a variety of home institutional pressures. Our findings are synthesized in our theoretical framework (Figure 3), which points to reputation risk, size of the business opportunity, and nonrecoverable investments as key moderators of the relationships between institutions and the strategic responses by firms, and low profile strategies in particular.

\section{Contributions}

The current study explored how restrictive home institutions impact on strategies, using a critical case of international business activities in Myanmar during 1996 to 2011, the period when the country was the target of institutional pressures to divest, particularly in Europe and North America. We thus extend the growing body of knowledge on how firms react to demands by stakeholders such as NGOs (Christmann, 2004, Doh \& Guay, 2006, Teegen, Doh \& Vachani, 2004, Yaziyi \& Doh, 2009) and the media (Spar, 1999). Especially our focus on local strategies of firms, as opposed to those at a head-quarter level, pushed forward an area largely ignored in international business research.

Our study also contributes to the area of human rights and business (Carswell, 1981, van Wyk et al., 2004, Holliday, 2005), in particular the question whether sanctions are able to achieve their aims of disrupting the host economy, or specific groups within the host society. Our framework and the qualitative data provide a more realistic understanding of how businesses react to home institutional pressure pointing in particular to differential impact across industries. In addition, important contributions are also made in an underresearched geography; international investment, trade and consumer behavior 
in emerging South-East Asian economies (Meyer, 2006, Tipton, 2007, Xu and Meyer, 2013), and Myanmar in particular (Lwin et al., 2006, Reid et al., 2001).

Myanmar 1996-2011 represents a 'critical case' (Flyvbjerg, 2006) where home institutions could be expected to be particularly constraining in their effects on business. While we have found this to be the case, we also observed that businesses even so are present in the country, in particular through low profile strategies. Considering effects of extra-territorial institutions more generally (i.e. rules that affect business in a country other than where the institutions originate), our case study provides some suggestive insights. All three forms of institutions occurring outside the target country - cognitive, normative and regulative - exert pressures on business and its strategic choices. Even without regulatory sanctions regime, in some cases, normative pressures (led by cognitive awareness) are effective in changing the behavior of business, although the effectiveness of this impact is moderated by industry and firmspecific factors.

\section{Future Research}

Having opened international business research into the complex net of home institutions on businesses operating in a politically sensitive context, we hope to stimulate further research. In the first instance, such research may test some of our propositions. To this end, the easing of the sanctions and the opening of the economy may provide opportunities for data-collection in Myanmar that hitherto have not been available; for example consumer surveys. Another approach would be to investigate other countries under international sanctions, such as Iran, Sudan and Cuba to identify and explain variations across host countries. 
A broader research agenda emerges with extra-territorial effects of institutions more generally. Institutions aiming to shape business activities outside their home country are a growing phenomenon, taking both formal forms, such as anti-corruption and anti-money laundering legislation, and informal forms such as normative pressures stimulated by NGOs. We lack at this time theoretical understanding of the roles of such extra-territorial institutions and their interactions with other pressures; we hope our research may stimulate such research as well.

\section{Conclusion}

Institutions affect business even when they operate outside their home country. Using Myanmar as a critical case of international business under adverse home country institutions, we explored the diversity of business responses. Our findings illustrate why normative pressure can be powerful in influencing firm strategy, even in the absence of regulative restrictions. Firms vary in their responses to institutional pressures due to differences in exposure to reputation risk, size of business opportunities and the non-recoverable nature of their investment. NGOs appear to be aware of such differential sensitivity to normative institutions and target their actions accordingly. Our framework may help all actors (NGOs, businesses, governments) aiming to influence institutions governing business operating outside their home country, and opens new avenues for research into the extra-territorial effects of institutions. 
Acknowledgements: the authors thank their colleagues and collaborators, especially AIB conference participants, the anonymous reviewers and editor Jonathan Doh for their helpful comments.

\section{References}

Alcatel Lucent 2010. Alcatel-Lucent did not deliver any system for filtering communications in Myanmar, http:/ / www.alcatel-lucent.com, retrieved 22 December 2011.

Asmus, D. F., \& Persechino, N. 1998. Oil and gas development projects. International Financial Law Review, 3-7.

BBC News, 2010. Who maintains sanctions on Burma? BBC website, 18 October, http:// www.bbc.co.uk/ news/ world-asia-pacific-11551130, retrieved 21 December 2011.

Bray, J. (2002). Burma: The dilemmas of commercial and humanitarian engagement. Corporate Environmental Strategy, 9(2): 155-162.

Brouthers, K. D. (1995). The influence of international risk on entry mode strategy in the computer software industry. Management International Review, 35(1): 7-28.

Brouthers, K.D. (2002). Institutional, Cultural and Transaction Cost Influences on Entry Mode Choice and Performance. Journal of International Business Studies, 33(2): 203-221.

Brouthers, K.D., Brouthers, L.E. \& Werner, S. (2002). Industrial sector, perceived environmental uncertainty and entry mode strategy. Journal of Business Research, 55(6): 495-507.

Burma Campaign UK. 2008. Insuring Repression, http:/ / burmacampaign.org.uk/ images/ uploads/ Insuring_Repression1002 10.pdf, retrieved January 10, 2012.

Carswell, R. (1981), Economic sanctions and the Iran experience. Foreign Affairs, 60: 247-265.

Charmaz, K. (2006). Coding in grounded theory practice, Constructing Grounded Theory: A Practical Guide Through Qualitative Analysis (pp. 57-60). London: SAGE Publications.

Charney, M. W. (2009). A History of Modern Burma (pp.148-200).Cambridge University Press.

Christmann, P. (2004). Multinational companies and the natural environment: Determinants of global environmental policy standardization. Academy of Management Journal, 47(5): 747-760. 
Cuervo-Cazurra, A. (2008). The effectiveness of laws against bribery abroad. Journal of International Business Studies, 39: 634-651.

Davidson, W.N., Worrell, D.L. \& El-Jelly, A. (1995). Influencing managers to change unpopular corporate behavior through boycotts and divestures: A stock market test. Business \& Society, 34: 177-196.

Dawar, N. \& Chattopadhay A. (2002). Rethinking marketing programmes for emerging markets. Long Range Planning, 35(5): 457-474.

Delios, A. \& Henisz, W. (2003). Policy uncertainty and the sequence of entry by Japanese firms, 1980-1998. Journal of International Business Studies, 34(3): 227-241.

Deng P. (2009). Why do Chinese firms tend to acquire strategic assets in international expansion? Journal of World Business, 44(1): 74-84.

Doh, J.P. (2005). Offshore outsourcing: Implications for international business and strategic management theory and practice. Journal of Management Studies, 42(3): 695: 704.

Doh, J.P. \& Guay, T. (2006). CSR, public policy, and NGO activism in Europe and the United States. Journal of Management Studies, 43: 47-73.

Doh, J.P., Howton, S. D., Howton, S. W., \& Siegel, D. S. (2010). Does the market respond to an endorsement of social responsibility? The role of institutions, information, and legitimacy. Journal of Management, 36(6): 1461-1485.

Donaldson, T. \& Preston, L. (1995). The stakeholder theory of the corporation. Academy of Management Review, 20: 65-91.

Driffield, N., Jones, C. \& Crotty, J. (2013). International business research and risky investments: An analysis of FDI in conflict zones. International Business Review, 22(1): 140-155.

EarthRights International. 2010. Oil companies in Burma urged to open their books, Press

Release, http:/ / www .earthrights.org/ sites/ default/ files/ documents/ press-releaseburma-revenue-transparency.pdf, retrieved January 4, 2011.

Eisenhardt, K. M. (1989). Building theories from case study approach.Academy of Management Review, 14(4): 532:550.

Elmore, M. (2007). Myanmar's rulers move against their 'worst enemy' - modern technology. Associated Press, September 28.

Energy Economist, (1998). Energy market report: Natural gas. Energy Economist, $7(2-2): 27$.

Estrin, S., Baghdasaryan, D. \& Meyer, K. E. (2009). Institutional Distance and Human Resource Distance in International Business Strategies in Emerging Economies. Journal of Management Studies, 46(7): 1171-1196.

European Union. (1996). Common Position of the Treaty on European Union, on Burma/ Myanmar. Official Journal L 287, November 8, p.001-002. 
Ferner, A., Quintanilla, J., \& Varul, M.Z. (2001). Country-of-origin effects, hostcountry effects, and the management of HR in multinationals: German companies in Britain and Spain. Journal of World Business, 26(2): 107-127.

Flyvbjerg, B. (2006). Five misunderstandings about case-study research. Qualitative Inquiry, 12(2): 219-245.

Fombrun, C. \& Shanley, M. (1999). What's in a name? Reputation building and corporate strategy. Academy of Management Journal, 33: 233-258.

Fulman, R. (1997). Investors push to cut Myanmar ties. Pensions and Investments, 25 (23): 38.

Frynas, J.G. (2005). The false developmental promise of Corporate Social Responsibility: evidence from multinational oil companies. International Affairs, 81(3): 581-598.

Global Investor (1995) Burma a pariah. Global Investor, 84 (Jul-Aug): 7-8.

Godfrey, P. C., Merrill, C. B. \& Hansen, J. M. (2009). The relationship between corporate social responsibility and shareholder value: an empirical test of the risk management hypothesis. Strategic Management Journal, 30: 425445.

Gooderham, P., Nordhaug, O. \& Ringdal, K. (1999). Institutional and Rational Determinants of Organizational Practices: Human Resource Management in European Firms. Administrative Science Quarterly, 44(3): 507-531.

Grosse, R., ed. (2003). International Business and Government Relations, Cambridge: Cambridge University Press.

Hartman, L.P., Shaw, B. \& Stevenson, R. (2003). Exploring the ethics and economics of global labor standards: A challenge to integrated social contract theory, Business Ethics Quarterly, 13(2): 193-220.

Hillman, A., \& Wan, W. (2005). The determinants of MNE subsidiaries' political strategies: Evidence of institutional duality. Journal of International Business Studies, 36: 322-340.

Hoffman, A.J. (1999). Institutional evolution and Change: Environmentalism and the U.S. chemical industry. Academy of Management Journal, 42(4): 351-371.

Holliday I. (2005). Rethinking the United States Myanmar policy. Asian Survey, 45(4): 603-621.

Holzmeyer, C. (2009). Human rights in an era of neoliberal globalization: The Alien Tort Claims Act and grassroots mobilization in Doe v. Unocal. Law \& Society Review, 43(2): 271-304.

Khanna, T. \& Palepu, K.G. (1997). Why focused strategies may be wrong for emerging markets. Harvard Business Review, 75, 41-51.

Khanna, T., Palepu, K. G. \& Bullock, R.J. (2010). Winning in Emerging Markets. Harvard Business School Press.

Khoury, T. \& Peng, M.W. (2011). Does institutional reform of intellectual property rights lead to more inbound FDI? Evidence from Latin America and the Caribbean. Journal of World Business, 46(3): 337-345. 
King, B.G. \& Soule, S.A. (2007). Social movements as extra-institutional entrepreneurs: The effect of protests on stock price returns. Administrative Science Quarterly, 52: 413-442.

Kobrin S.J. (1987). Testing the bargaining hypothesis in the manufacturing sector in developing countries. International Organization, 41: 63-75.

Kolk, A. \& van Tulder, R. (2004). Ethics in international business: multinational approaches to child labor. Journal of World Business, 39(1): 49-60.

Kostova, T. (1999). Transnational transfer of strategic organizational practices: A contextual perspective. Academy of Management Review 24(2): 308-324.

Kostova, T., Roth, K. \& Dacin, M.T. (2008). Institutional theory in the study of multinational corporations: A critique and new directions. Academy of Management Review, 33(4): 994-1006.

Kourula, A. (2011). Corporate engagement with non-governmental organizations in different institutional contexts-A case study of a forest products company. Journal of World Business, 45(4): 395-404.

Kumar, R., Lamb, W.B. \& Wokutch, R.E. (2002). The end of the South African sanctions, institutional ownership, and the stock price performance of boycotted firms. Business and Society, 41(2), 133-165.

Kudo, T., (2005). The impact of United States sanctions on the Myanmar garment industry.Chiba: JETRO Institute of Developing Economies, Discussion Paper No. 42, December.

Kwok, C.C.Y. \& Tadesse, S. (2006). The MNC as an agent of change for hostcountry institutions: FDI and corruption. Journal of International Business Studies, 37(6): 767-785.

Lugar, R. \& Cardin, B. (2010), U.S. PWYP Law 2010 - Sec. 1504. Dodd-Frank Wall Street Reform Act.

Luo Y.D., Xue Q. \& Han B. (2010). How emerging market governments promote outward FDI: Experience from China. Journal of World Business, 45(1): 6879.

Lwin, M., Pecotich, A. \& Thein, V. (2006). Myanmar, in A. Pecotich and C.J. Shultz (Eds.), Handbook of Markets and Economies: East Asia, South-East Asia, Australia, and New Zealand (pp.447-476). New York: M.E. Sharpe Inc.

Mahon, J. F. (2002). Corporate reputation: A research agenda using strategy and stakeholder literature. Business and Society, 41(4), 415-445.

Martin, M.F. (2012). U.S. Sanction on Burma. CRS Report for Congress, , Washington, DC: Congressional Research Service.

McCarthy, S. (2000). Ten years of chaos in Burma: Foreign investment and economic liberalization under the SLORC-SPDC 1988-1998. Pacific Affairs, 73(2): 233-262.

Meyer, K. E. (2006). Asian management research needs more self-confidence. Asia Pacific Journal of Management, 23, 119-137. 
Meyer, K.E., Estrin, S., Bhaumik, S.K. \& Peng, M.W. (2009). Institutions, resources, and entry strategies in emerging economies. Strategic Management Journal, 30(1): 61-80.

Meyer, K. E. \& Thaijongrak, O. (2013). The dynamics of emerging economy MNEs: How the internationalization process model can guide future research. Asia Pacific Journal of Management, advance online, .

Meyer, K.E. \& Xia, H. (2012). British entrepreneurs, global vision. Business Strategy Review, 23(2): 52-57.

Moe, W. (2008). Price of cell phones falls in Burma. The Irrawaddy, January 24.

Morck R., Yeung B. \& Zhao M. (2008). Perspectives on China's outward foreign direct investment. Journal of International Business Studies, 39(3): 337-350.

Musteen, M. Rhyne L. \& Zheng, C. (2013). Asset or constraint: Corporate reputation and MNCs' involvement in the least developed countries. Journal of World Business, advance online, doi:j.jwb.2012.07.016.

Nebus, J. \& Ruffin, C. (2010). Extending the bargaining power model: Explaining bargaining outcomes among nations, MNEs, and NGOs. Journal of International Business Studies, 41(6): 996-1015.

Nguyen, T.V., Le, N.T.B. \& Bryant, S.E. (2013). Sub-national institutions, firm strategies, and firm performance: A multilevel study of private manufacturing firms in Vietnam. Journal of World Business, 48(1): 68-76.

Oetzel, J. \& Ketz, K. (2012). Why and how might firms respond strategically to violent conflict? Journal of International Business Studies, 42: 166-186.

Oil and Gas Journal. (1995). Green light given for Myanmar's first offshore development, 93(7): 28-30, Feb 13.

Oil and Gas Journal. (1997). Human rights and sanctions, 95(7): 19, February 17.

Oil and Gas Journal. (2000). Myanmar's upstream sector hobbled, 98(26): 24-27, June 26.

Ozawa, T. (1979). International investment and industrial structure, Oxford Economic Papers, 31, 72-92.

Pananond, P. (2007). The changing dynamics of Thai multinationalsafter the Asian economic crisis. Journal of International Management, 13(3): 356-375.

Pape, R.A. (1997). Why economic sanctions do not work. International Security, 22: $90-136$.

Parker, C., \& K. Sam. (2005). Internet Censorship in Burma Worsening. The Irrawaddy Online Edition October 12, 2005: http:/ / www.irrawaddy.org/ aviewer.asp?a=5074\&z=153, retrieved March 8, 2006.

Patton, M. Q. (2002). Qualitative Research \& Evaluation Methods. 3rd ed. Thousand Oaks, California: Sage Publications, Inc.

Pedersen, M.B. (2000). International policy on Burma: Coercion, persuasion, or cooperation? Assessing the claims. In M. B. Pedersen, E. Rudland, \& R. J. May (Eds.), Burma Myanmar: Strong regime weak state? (pp. 195-240). Hurst and Co. 
Peng, M.W. (2003). Institutional transitions and strategic choices. Academy of Management Review, 28, 275-296.

Peng, M. W., Wang, D. Y. \& Jiang, Y. (2008). An institution-based view of international business strategy: a focus on emerging economies. Journal of International Business Studies, 39, 920-936.

Poulis K., Poulis E. \& Plakoyannaki, E. (2013). The role of context in case study selection: An international business perspective, International Business Review, 22(1): 304-314.

Ramamuti, R. (2001). The Obsolescing 'Bargaining Model'? MNC-Host Developing Country Relations Revisited. Journal of International Business Studies, 32(1): 23-39.

Reh, L. (2005). Daewoo urged to quit Arakan gas field project. The Irrawaddy, October 14.

Rehbein, K., Waddock, S., \& Graves, S.B. (2004). Understanding Shareholder Activism: Which Corporations are Targeted?. Business \& Society, 43(3): 239-267.

Reid, D., Walsh, J. \& Yamona, M. (2001). Quasi-legal commerce in Southeast Asia: Evidence from Myanmar. Thunderbird International Business Review, 43(2): 199-221.

Sharma S. \& Henriques, I. (2005). Stakeholder influences on sustainability practices in the Canadian forest products industry. Strategic Management Journal, 26: 159-180

Silverstein, J. (2001), Burma and the world: A decade of foreign policy under the state law and order restoration council, in R. Taylor (ed). Burma: Political Economy under Military Rule (pp. 119-137). London, UK: Hurst \& Company.

Spar, D.L. (1998). The spotlight and the Bottom Line. Foreign Affairs, 77: 7-12.

Spar, D.L. \& Yoffie, D. (1999). Multinational enterprises and the prospect for Justice. Journal of International Affairs, 52: 557-581.

Stopford, J. \& Strange, S. (1991). Rival Firms, Rival States, Cambridge: Cambridge University Press.

Strauss, A. L. \& Corbin, J. (1990). Basics of Qualitative Research: Grounded Theory Procedures and Techniques, Newbury Park, California: Sage Publications.

Teegen, H. (2003). International NGOs as global institutions. Journal of International Management. 9: 271-285.

Teegen, H., Doh, J.P., \& Vachani, S. (2004). The importance of nongovernmental organizations (NGOs) in global governance and value creation: An international business research agenda. Journal of International Business Studies, 35: 463-483.

The Australian. (2007). Oil firms continue to pump support. October 01.

The Irrawaddy. (2005a). Burma signs oil deals. February.

The Irrawaddy. (2005b). Bad news for Burma. October 21. 
The World Factbook. (2012) Burma, CIA.

https:/ / www.cia.gov/ library/ publications/ the-world-

factbook/ geos/ bm.html, retrieved 15th June 2012.

Thein, V. H. H. (2003). International Business Development Strategies in Embargoed Markets: The Myanmar Case, Doctoral Thesis. Perth: Australia:Curtin University.

Thein, H. H., \& Pick, D. (2009). International trade and business investment in Myanmar: Scope, strategic development, and social implications. In M. Gillan and B. Pokrant (Eds.), Trade, Labour, and Transformation of Community in Asia (pp. 36-68). Palgrave Macmillan.

Tipton, F.B. (2009). Southeast Asian capitalism, Asia Pacific Journal of Management, 26: 401-434.

Torbat, A.E., (2005). Impacts of the US Trade and Financial sanctions on Iran. World Economy, 28: 407-434.

van Wyk, J., Dahmer, W. \& Custy, M. (2004). Risk management and the business environment in South Africa. Long Range Planning, 37: 259-276.

Vogel, T. (2009). EU extends sanctions on Myanmar until 2010. European Voice, http:/ / www .europeanvoice.com/ article/ 2009/ 04/ eu-extends-sanctionson-myanmar-until-2010/ 64716.aspx, retrieved 21 st Dec 2011.

Voice of America (2009). Oil firms accused of whitewashing Burma pipeline abuses by military rulers. VOA News, http:/ / www.voanews.com/ english/ news/ a-13-2009-09-10-voa9-68758992.html, retrieved 4 January 2011.

Wang, C.Q., Hong, J.J., Kafouros, M. \& Wright, M. (2012). Exploring the role of government involvement in outward FDI from emerging economies. Journal of International Business Studies, 43: 655-676.

Welch, C., Piekkari, R., Plakoyiannaki E. \& Paavilainen-Mäntymäki, E. (2011). Theorising from case studies: Towards a pluralist future for international business research. Journal of International Business Studies, 42: 740-762.

Wernick. D.A. (2011). Secondary stakeholder legal action and stock market performance: An event study of Alien Tort Statute Litigation filed against multinational enterprises 1993-2003, Essay II of PhD dissertation, Florida International University. http:/ / digitalcommons.fiu.edu, accessed August 2012.

Xu, Dean \& Meyer, Klaus E. (2013). Linking theory and context: Strategy research in emerging economies, Journal of Management Studies, advance online.

Yang, X., Jiang, Y., Kang, R. \& Ke, Y. (2007) A comparative analysis of the internationalization of Chinese and Japanese firms. Asia Pacific Journal of Management, 26, 141-162.

Yaziji, M. \& Doh, J. (2009). NGOs and Corporations: Conflict and Corporations, Cambridge: Cambridge University Press.

Zucker, L. (1983). Organizations as institutions. In S. Bacharach, S. (ed.), Research in the sociology of organizations (pp. 1-47). Greewich, C: JAI Press. 
Table 1: Timeline: Myanmar, the USA and supra-national organizations

\begin{tabular}{|c|c|c|c|}
\hline & Events in Burma & $\begin{array}{c}\text { Reactions of supra- } \\
\text { national organizations }\end{array}$ & Reactions by US authorities \\
\hline $1960 s$ & $\begin{array}{l}\text { 1962: Coup d'etat staged } \\
\text { by the military starts } \\
\text { socialist style development } \\
\text { policies }\end{array}$ & None & None \\
\hline 1970s & $\begin{array}{l}\text { Ongoing military rule with } \\
\text { socialist style economic } \\
\text { policies }\end{array}$ & None & None \\
\hline 1980s & $\begin{array}{l}\text { 1987/88: Popular protests } \\
\text { against military rules were } \\
\text { eventually squashed. }\end{array}$ & $\begin{array}{l}\text { 1988: suspension of non- } \\
\text { humanitarian aid by the } \\
\text { Western nations and } \\
\text { Japan; the World Bank and } \\
\text { IMF cease lending }\end{array}$ & $\begin{array}{l}1989 \text { (USA): discontinuation } \\
\text { of preferential trade } \\
\text { arrangements }\end{array}$ \\
\hline 1990s & $\begin{array}{l}\text { 1990: Parliamentary } \\
\text { election won by the } \\
\text { National League for } \\
\text { Democracy ( } 59.9 \% \text { of } \\
\text { votes) ahead of the } \\
\text { military's National Unit } \\
\text { Party ( } 21.2 \% \text { ). However, } \\
\text { parliament was never } \\
\text { convened, opposition } \\
\text { leaders were arrested and } \\
\text { detailed, Aung San Suu Kyi } \\
\text { under house arrest. } \\
\text { 1995: Temporary release } \\
\text { of Aung San Suu Kyi from } \\
\text { house arrest; increased } \\
\text { crackdown on democratic } \\
\text { movements and ethnic } \\
\text { minorities in border areas }\end{array}$ & $\begin{array}{l}\mathbf{1 9 9 0} \text { - } \mathbf{2 0 0 0}(\mathbf{U N}) \text { : the } \\
\text { Commission on Human } \\
\text { Rights several times called } \\
\text { for the Myanmar } \\
\text { government to improve its } \\
\text { human rights records } \\
\mathbf{1 9 9 1} \text { (UN): the General } \\
\text { Assembly issued strong } \\
\text { resolutions against } \\
\text { Myanmar } \\
\mathbf{1 9 9 7} \text { (ASEAN): admitted } \\
\text { Myanmar as a member } \\
\mathbf{1 9 9 8} \text { (ILO): the } \\
\text { International Labor } \\
\text { Organization issued a } \\
\text { report on forced labor in } \\
\text { Myanmar }\end{array}$ & $\begin{array}{l}\text { 1990: Section } 138 \text { of Customs } \\
\text { and Trade Act requires the } \\
\text { President to impose economic } \\
\text { sanctions (basis for EO } 13047 \\
\text { in 1997). } \\
\text { 1991: Bilateral textile } \\
\text { agreement lapsed and was not } \\
\text { renewed. } \\
\text { 1997: Executive Order } 13047 \\
\text { bans all new investments in } \\
\text { Burma } \\
\text { 1997: tariff preferences to } \\
\text { Myanmar were withdrawn }\end{array}$ \\
\hline 2000 s & $\begin{array}{l}\text { 2007: widespread } \\
\text { demonstrations led by } \\
\text { Buddhist monks. }\end{array}$ & $\begin{array}{l}2009(\mathbf{E U}) \text { : ban on } \\
\text { imports of Myanmar } \\
\text { timber, metals and } \\
\text { precious stones. }\end{array}$ & $\begin{array}{l}\text { 2003: Burmese Freedom and } \\
\text { Democracy Act and Executive } \\
\text { Order } 13310 \text { prohibit the } \\
\text { provision of financial services } \\
\text { to Myanmar. } \\
\text { 2008: Tom Lantos Block } \\
\text { Burmese Jade Act bans import } \\
\text { of products containing } \\
\text { Burmese jadeite and rubies. }\end{array}$ \\
\hline 2010s & $\begin{array}{l}\text { 2011: Aung San Suu Kyi } \\
\text { released from house arrest, } \\
\text { and elected to parliament } \\
\text { in a by-election }\end{array}$ & $\begin{array}{l}2012(\mathbf{E U}) \text { : sanctions } \\
\text { gradually phased out }\end{array}$ & $\begin{array}{l}\text { 2011: Secretary Clinton visits } \\
\text { Burma. } \\
\text { 2012: sanctions gradually } \\
\text { phased out }\end{array}$ \\
\hline
\end{tabular}

Note: This table does not cover sanctions aimed directly against individuals associated with the

Burmese military, such as visa bans and freezing of assets.

Sources: Complied by the authors based on text in Charney, 2009, Martin, 2012, Pederson, 2000

and Silverstein, 2001. 
Table 2: Summary of Interviews

\begin{tabular}{|c|c|c|c|c|c|c|c|c|c|c|}
\hline & \multicolumn{4}{|c|}{ Interviewees by Nationality } & \multicolumn{5}{|c|}{ Interviews (a) } & \multirow{3}{*}{$\begin{array}{l}\text { Interviewee } \\
\text { reference code }\end{array}$} \\
\hline & \multirow[t]{2}{*}{ Myanmar } & \multirow{2}{*}{$\begin{array}{l}\text { Other } \\
\text { Asian }\end{array}$} & \multirow{2}{*}{ Europe } & \multirow{2}{*}{ US } & \multicolumn{3}{|c|}{ Myanmar } & \multicolumn{2}{|c|}{ Overseas } & \\
\hline & & & & & 1996-98 & 2007 & 2010-12 & 2010 & 2012 & \\
\hline Oil and gas & 6 & & & & & & 7 & & & A1 to A6 \\
\hline $\begin{array}{l}\text { Garment } \\
\text { manufacturing }\end{array}$ & 8 & 1 & & & 3 & 1 & 5 & & & $\mathrm{~B} 1$ to $\mathrm{B} 9$ \\
\hline Telecommunication & 8 & 1 & & & & & 9 & & & $\mathrm{C} 1$ to $\mathrm{C} 9$ \\
\hline $\begin{array}{l}\text { International } \\
\text { consumer goods }\end{array}$ & 16 & 7 & 3 & & 29 & 3 & & 1 & & D1 to D26 \\
\hline Country expert & 3 & & 1 & & 4 & & & 1 & & W1 to W4 \\
\hline $\begin{array}{l}\text { Advertising agency } \\
\& \text { Media } \\
\text { consultancy }\end{array}$ & 3 & 2 & 1 & & 11 & & & & & $\mathrm{X} 1$ to $\mathrm{X} 6$ \\
\hline US State Department & & & & 2 & & & & & 2 & Y1 to Y2 \\
\hline
\end{tabular}

Notes: (a) the total number of interviews exceeds the number of interviewees as several interviewees have been interviewed several times. 


\section{Table 3: Industry Contexts}

\begin{tabular}{|c|c|c|c|}
\hline Industry & $\begin{array}{c}\text { Business } \\
\text { Opportunities }\end{array}$ & Sensitive Issues & Home Institutions \\
\hline $\begin{array}{l}\text { Resource-seeking } \\
\text { Capital Intensive } \\
\text { (mining, oil \& gas,) }\end{array}$ & $\begin{array}{l}\text { Availability of natural } \\
\text { resources that are } \\
\text { scarce on the world } \\
\text { market } \\
\text { Construction } \\
\text { opportunities in } \\
\text { industry-specific } \\
\text { infrastructure such as } \\
\text { pipelines, ports etc }\end{array}$ & $\begin{array}{l}\square \text { The contribution to local employment } \\
\square \text { Distribution of wealth generated from } \\
\text { projects } \\
\square \text { Environmental and human rights impact } \\
\text { (including displacement of local } \\
\text { communities) } \\
\square \quad \text { Ethnic tension and conflict } \\
\square \text { Partnering with a government with poor } \\
\text { human rights record } \\
\square \text { Governance issues in ethnic minority areas }\end{array}$ & $\begin{array}{l}\text { Cognitive: increased awareness of situation in } \\
\text { Myanmar due to NGO campaigns and media reports } \\
\text { specifically focused on the oil and gas sector; } \\
\text { Normative: reduced legitimacy of business operations } \\
\text { in Myanmar, pressures to divest because operations in } \\
\text { Myanmar are branded as unethical } \\
\text { Regulative (USA): (1) } 1997 \text { government ban on new } \\
\text { investment in Myanmar, (2) } 1789 \text { Alien Tort Claims } \\
\text { Act, (3) } 2010 \text { Dodd-Frank Wall St Reform Act requiring } \\
\text { US companies to reveal financial transactions with host } \\
\text { governments. }\end{array}$ \\
\hline $\begin{array}{l}\text { Resource-seeking } \\
\text { labor intensive } \\
\text { (Garments) } \\
\text { manufacturing) }\end{array}$ & $\begin{array}{l}\text { Exploitation of low cost } \\
\text { labor; } \\
\text { Bypass MFA trade } \\
\text { restriction affecting } \\
\text { other Asian economies } \\
\text { (before 2005) }\end{array}$ & $\begin{array}{l}\square \text { Consumer sensibility for country of origin } \\
\text { image (in US and EU) } \\
\square \text { Labor standards and human rights for } \\
\text { workers in garment manufacturing }\end{array}$ & $\begin{array}{l}\text { Cognitive: increased awareness of situation in } \\
\text { Myanmar due to NGO and trade union campaigns and } \\
\text { media reports; } \\
\text { Normative: reduced legitimacy of products made in or } \\
\text { associated with Myanmar, partially enforced via } \\
\text { consumer boycott actions; } \\
\text { Regulative: Global MFN agreement which expired in } \\
\text { 2005; (USA): } 2003 \text { Burma Freedom and Democracy Act } \\
\text { ban 'Made in Myanmar' garments. }\end{array}$ \\
\hline $\begin{array}{l}\text { Market-seeking } \\
\text { capital intensive } \\
\text { (Telecommunication) }\end{array}$ & $\begin{array}{l}\text { Local market potential } \\
\text { in telecommunication } \\
\text { infrastructure and } \\
\text { operations }\end{array}$ & $\begin{array}{l}\text { Potential military use of infrastructure and } \\
\text { telecommunication } \\
\square \text { Freedom of speech and potential for } \\
\text { monitoring opposition groups } \\
\square \text { Partnering with a government with poor } \\
\text { human rights record }\end{array}$ & $\begin{array}{l}\text { Cognitive: increased awareness of situation in } \\
\text { Myanmar in general due to NGO campaigns and media } \\
\text { reports; } \\
\text { Normative: reduced legitimacy of business operations } \\
\text { in Myanmar, and co-investments with government } \\
\text { associated businesses in particular. } \\
\text { Regulative: } 1997 \text { government ban on new investment }\end{array}$ \\
\hline
\end{tabular}


in Myanmar .

\begin{tabular}{|c|c|c|c|c|c|}
\hline $\begin{array}{l}\text { Market-seeking labor } \\
\text { intensive } \\
\text { (Consumer Goods) }\end{array}$ & $\square$ & $\begin{array}{l}\text { Current demand, albeit } \\
\text { small }\end{array}$ & & $\begin{array}{l}\text { Impact of Myanmar market activity on } \\
\text { global brand image }\end{array}$ & $\begin{array}{l}\text { Cognitive: increased awareness of situation in } \\
\text { Myanmar in general due to NGO campaigns and media } \\
\text { reports. }\end{array}$ \\
\hline & & advantages in view of & & imports of consumer goods & $\begin{array}{l}\text { Normative: reduced legitimacy of business operations } \\
\text { in }\end{array}$ \\
\hline & & $\begin{array}{l}\text { long term local market } \\
\text { potential }\end{array}$ & $\square$ & $\begin{array}{l}\text { Corruption and absence of genuine } \\
\text { competition }\end{array}$ & $\begin{array}{l}\text { in Myanmar. } \\
\text { Regulative: proposed but never implemented } \\
\text { Massachusetts selective purchasing law. }\end{array}$ \\
\hline
\end{tabular}


Table 4: Business Responses in Quotations

\section{Industry On Businesses that Left On Businesses that Stayed}

Resource-seeking [A-out1] "Oh, of course, yes, many did withdraw. The Capital Intensive nature of the oil business is very uncertain, the finds are (mining, oil \& gas) unpredictable. Although you are spending lots and lots on exploration works, no one can guarantee that you will find oil and will be commercially viable. There are lots of risks. Some companies left in the middle of exploration work. In oil/ gas, you have to use indirect methods, in finding. Form a hypothesis and explore, but there are lots other influencing factors, and it is very uncertain. Both Western and Asian companies face these problems. They exit because of these uncertainties. They started and showed negative results and they have spent quite a bit and decided not to continue. And left. Not because of activists' pressures. Shell (the Dutch company) left because they couldn't find commercial quantity" [interviewee A1, 2012].

[A-in-1] "Offshore, there are about 20 companies and onshore also about that many. Mostly Asian companies, Chinese, Thais and Malaysian and Indonesian. Not that many Western right now [20 January 2012]. There is Total and their partner Unocal/ Chevron. There are Japanese, but they are partners. As operators, you will have mostly Thailand, Korea Daewoo and CNOOC. CNOOC is China's third biggest national oil company." [Interviewee A1, 2012]

[A-in-2] "Chinese companies certainly have a strong foothold; sector-wise I am not so sure, but they have gone into long term contracts (30/ 40 years) for a lot of things. The extractive industries, it has. Well, Burma opening up now, and the Chinese opposes it ... In competing against Chinese, I don't say that we have an advantage over Chinese. Chinese businesses have already taken first steps; they have a first-mover advantage" [Interviewee C1, 2012]

[A-in-3] "Total won't leave as it has committed such a big investment, has already built the pipeline and that can't be left alone and has already signed contract etc. with the Thai side, to sell the gas. How could they leave now? They have to stay put, but they don't expand any further. They have enough problems maintaining what they have got (the pipeline), rather than expanding. They are not involved in any new projects. Just the pipeline, they have maintained" [Interviewee A3, 2012].

Resource-seeking

Capital Non-intensive

(Garments

manufacturing)
[B-out1] "The formal sanctions on garments (made in Burma) came in ... 2003. But it has been starting a bit before that. In 2000, there has been a petition from business to lift the sanctions, and that somewhat delayed imposition of the sanctions, until 2003; then the formal sanctions were imposed." (Interviewee B1, 2012).

[B-out2] "There were nearly 400 factories in 2000, the lowest time for this industry is 2004/2005, then only 170 factories left in Myanmar. So over 100 factories closed.
[B-in1] "In Thailand, they might put buttons on clothes sent from Myanmar and call it 'Made in Thailand,' it can be done very easily, therefore, I don't think these restrictions are effective, business people always find a way around whatever restrictions are placed on them". [Interviewee B4, 2012].

[B-in2] "The impact on the garment business is huge too. Because of the sanctions, for those garment manufacturers who remained despite the sanctions, they had to do business indirectly, instead of getting business from clothing labels themselves, and therefore they can't get the prevailing market prices. They have become subcontractors, sneaking around to get the 
Very big impact! 200, 000 laborers lost the job.... Before sanctions were imposed, there were more foreign players in that sector, but a lot of them withdrew because of sanctions. Another reason for foreign company's withdrawals also had to do with the issue of quota [under MFN]. When quota restrictions were dismantled, they no longer needed Myanmar for a reason for quota." (Interviewee B2, 2012)

[B-out3] "...well, after year 2000, a lot of them withdrew, because they had US buyers. At the time, $80 \%$ of buyers/ brands were from the US ... We, at the time, focused a lot on the US market. The buyers withdrew because of sanctions. Year 2000 was a peak period for the garment factories here. We had nearly 4000 factories here. Starting from 2001/2, it started to decline" (Interviewee B1, 2012).

[B-out4] "Hwa Foo [is] the Chinese company that was manufacturing for Adidas. In that case, Hwa Foo had to leave Myanmar too. The investment isn't that much and therefore it wasn't that big a deal to leave. The building belonged to the government and the only issue is the machinery that can be sold to others. .... It is labor intensive, but not capital intensive, it is easy to withdraw" [Interviewee B1, 2012].

Market-seeking
Capital Intensive (Telecommunication)
[C-out1] "About telecommunication industry, currently we have three areas: 1 . Selling accessories, 2 . Service provisions and 3. Building infrastructure. Service provision is still completely controlled by the government, no outsider yet. In service provisions, the local businesses are all competing with each other, very complicated. The only area, foreigners are allowed to be involved for now is in infrastructure building. That's all, for the rest of the telecom industry, no foreign business, only the local firms competing with each other." business and operate secret operations etc. So people at the grassroot level were the ones who suffered as a result of Western sanctions. Same things with gemstones, they don't get the market price. We get the thief prices." [Interviewee B3, 2012].

[B-in3] "Daewoo, Segyl, most of the Korean companies, Chinese and Taiwan companies, they remained here. They switched the market from the US to European countries, mostly Germany brands, and even the Latin American market, and also the Japanese market. But, the quality control for the

Japanese market is very high, higher than the US market. If we have a chance, we all prefer a US buyers/ market as they pay us more for CMP [Cut, Making and Packagingl and it is more profitable. And the US quality control is lower than others and the pieces for the US market aren't that difficult to make." [Interviewee B2, 2012].

[B-in4] "There is more profit making clothes for the local market. Roughly, my profit per a garment item is $\$ 1.50$, compared to only $\$ 8$ for a dozen items. So, more profit from the local market." [Interviewee B6, 2012]

[B-in5] "The foreign investors in the garment industry are from Taiwan and Korea and China. They are the majority. They do, what we call, CMP [Cut Making and Packaging]. They represent lots of brands. Some of them are joint ventures and some are wholly owned. Some do have local partners" [interviewee B1, 2012].

[C-in1] "Alcatel was in partnership with Shanghai Bell (SB). When Shanghai Bell sold telecom equipment to Myanmar, because of the partnership connection between Alcatel and SB, Alcatel got into trouble with activists." [Interviewee C9, 2012]

[C-in2] "I helped set up [this company] about ten years ago. It is okay for the company. It stayed throughout the sanctions era. No impact" [Interviewee C9, 2012]

[C-in3] "As far as foreign investment is concerned, the only area currently that has foreign companies participating is in selling equipment. Right now, we have three foreign companies selling telecom equipments to the 

in, after the sanctions." (Interview C9, 2012).

Market-seeking Capital Non-intensive

(Consumer Goods)
[D-out1] "For Pepsi, the headquarter themselves

decided to withdraw. It was under pressure. But for us, ... [Western alcohol brand], they would not pull out like Pepsi did. But they keep it just low profile, meaning they don't do any promotional program more than what the EU and US sanctions allow. (Interviewee D13, 1997).

[D-out2] But whatever many we had have pulled out. [The American research company] pulled out. They have been here only one to two years, they are an America company. They had to leave. [A American film brand] had to leave too because of American trade sanctions (Interviewee X2, 1997/98)

[D-out3] I am sure that they will try to facilitate that on the border area and whatever they can. I don't think that was a major strategy or anything like that. They don't need to be involved; the demand was so high that the smugglers will satisfy that demand. Also it keeps the cigarettes fresh, because after a few months, cigarettes do get stale. So, smugglers will supply some limited amount of fresh stuff on the market and keep the brand alive for the parent company (Interviewee X2, 1997/ 98).

[D-out4] Product will run out legally, but illegally the product will still be around. They withdraw the marketing, they withdraw the correct channel to bring the product in, but the product will still probably come through other channel. There are already businesses going around and buying up the stocks. Hold on to it and resell it at a higher price. (Interviewee X1, 1997/98).
[D-in-1] "Many expatriates working in different companies have been pulled back either to Thailand, or Vietnam. But their office remained and run by the locals now." (Interviewee D11, 1996/97)

[D-in-2] 'Yeah, actually they can go to the outskirts and do it. Don't do it in Yangon, it's fine. Yangon, Mandalay, nobody knows where you are. And a lot of these places, there's a lot of local population that a foreigner can't go.

Right? And that's the place you can sell, why are you worrying? The market

is big. So you don't do it in Yangon and Mandalay." (Interviewee X1, 1997).

[D-in-3] "Yes, they [a European consumer giant] are afraid of trade sanctions. They don't advertise much, instead they...go to country side and ..."yell" around the country, ......give out samples and explain the product." (Interviewee X5, 1998)

[D-in-4] "[an American brand] is probably a good example. They did not want to do billboards because that is a bit too permanent. But they still advertise on TV. Because it is 30 sec and gone, right, billboards are there 24 hours a day" (Interviewee X3,1998).

[D-in-5] "People can take photographs [of billboards], so TV is good, you know, it just come and go, it's one flash and no-one else will see. That problem only applies to Yangon" (Interviewee X4, 1998).

[D-in6] "[Japanese manufacturers] are scared. They have millions of sales volume in US. Here they have let's say only [small number] of units per year. Even $1 \%$ drop in sales over in US is bigger than what they will get from this market. Plainly speaking, they are even now asking to pull down some of the billboards. They don't support billboards any more. They used to support before. They used to pay for the costs, but now they not only did not pay for the costs, they are asking to pull [them] down." (Interviewee X1, 1998).

(D-in7) We, as [the company], do not sell. We sell to importer's hands. Any importer can buy what they like, any amount. Just importer brings the goods in and sells them here. The only thing, if we don't sell, of course, importer can't get the goods. So our main [task] is supplying to this importer and he 
distributes for us and we also appoint the distributor (Interviewee D26, 1998).

[D-in8] "Are they [the manufacturer] a bit concerned about international politics [US sanctions]? No, because, although we deal with England company, our products are from Indonesia, so they are an ASEAN product. And our trading is with Singapore, so we in fact we have nothing to do with England." (Interviewee D12, 1998).

[D-in9] "But [the American brand] has been smart because while they advertised on television, they don't do outdoor advertising, in terms of billboards, don't do press advertising, which journalists can pick up on easily. But for TV, it is harder to pick up on. It is really smart. They do a lot of POPs [point of purchase] trades and a little tin plate sign for restaurants. Billboards and newspaper advertising, easy to get hold of it by journalists. [They] will be under pressure because it is U.S. company." (Interviewee X2, 1998)). 
Table 5: Open coding process: Low profile strategies

\begin{tabular}{|l|l|l|l|}
\hline Step 1: Underline key terms on the quotes & $\begin{array}{l}\text { Step 2: } \\
\text { Restating key } \\
\text { phrases }\end{array}$ & $\begin{array}{l}\text { Step 3: } \\
\text { developing and } \\
\text { naming } \\
\text { concepts }\end{array}$ & $\begin{array}{l}\text { Step 4: } \\
\text { developing } \\
\text { and naming } \\
\text { categories }\end{array}$ \\
\hline $\begin{array}{l}\text { [Indirect-1] "The impact on the garment business is huge too. Because of the } \\
\text { sanctions, for those garment manufacturers who remained despite the sanctions, } \\
\text { they had to do business indirectly, instead of getting business from clothing labels } \\
\text { themselves, and therefore they can't get the prevailing market prices. They have } \\
\text { become subcontractors, sneaking around to get the business and operate secret } \\
\text { operations etc." [Interviewee B3,2012]. }\end{array}$ & $\begin{array}{l}\text { Do business } \\
\text { indirectly } \\
\text { [Indirect-2] "[The brand] withdrew all dealership, because it was an American } \\
\text { company. But they have a company in Singapore; that company buys for them. So } \\
\text { instead of direct, they are doing indirect." (Interviewee D19, 1998). }\end{array}$ & $\begin{array}{l}\text { Doing indirect } \\
\text { via distributors } \\
\text { (consumer } \\
\text { goods) } \\
\text { [Indirect-3] “In Thailand, they might put buttons on clothes sent from Myanmar and } \\
\text { call it 'Made in Thailand,' it can be done very easily, therefore, I don't think these } \\
\text { restrictions are effective, business people always find a way around whatever } \\
\text { restrictions are placed on them". [Interviewee B7, 2012] }\end{array}$ & $\begin{array}{l}\text { Find a way } \\
\text { around } \\
\text { via a third } \\
\text { country } \\
\text { (garments; } \\
\text { consumer goods; } \\
\text { telecom) }\end{array}$ \\
\hline $\begin{array}{l}\text { [Reduced-1] "Banks rep offices have pulled out including UOB, Thai Military bank } \\
\text { and Thai bank. Some had expatriates called back, but just the local guys are left } \\
\text { there." [Interviewee X2, 1996/97] } \\
\text { [Reduced-2] "Many expatriates working in different companies have been pulled } \\
\text { back either to Thailand, or Vietnam. But their office remained and run by the locals } \\
\text { now." [Interviewee D11, 1996/ 97] }\end{array}$ & Called back & $\begin{array}{l}\text { Reduced local } \\
\text { presence } \\
\text { (garments, } \\
\text { telecom and } \\
\text { consumer goods) }\end{array}$ & $\begin{array}{l}\text { Iow profile } \\
\text { strategies' }\end{array}$ \\
\hline
\end{tabular}




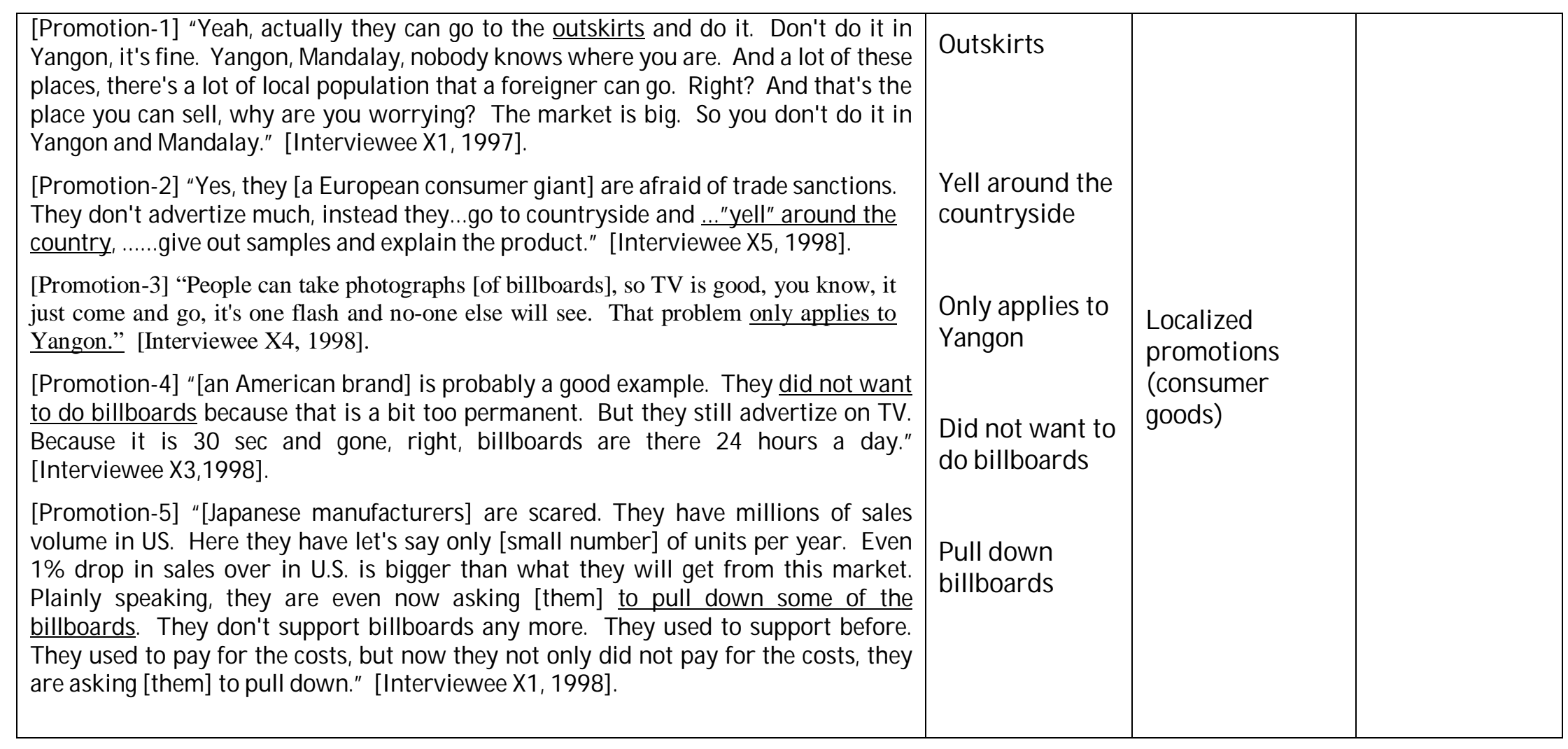


Figure 1: Initial Theoretical Framework for Analysis

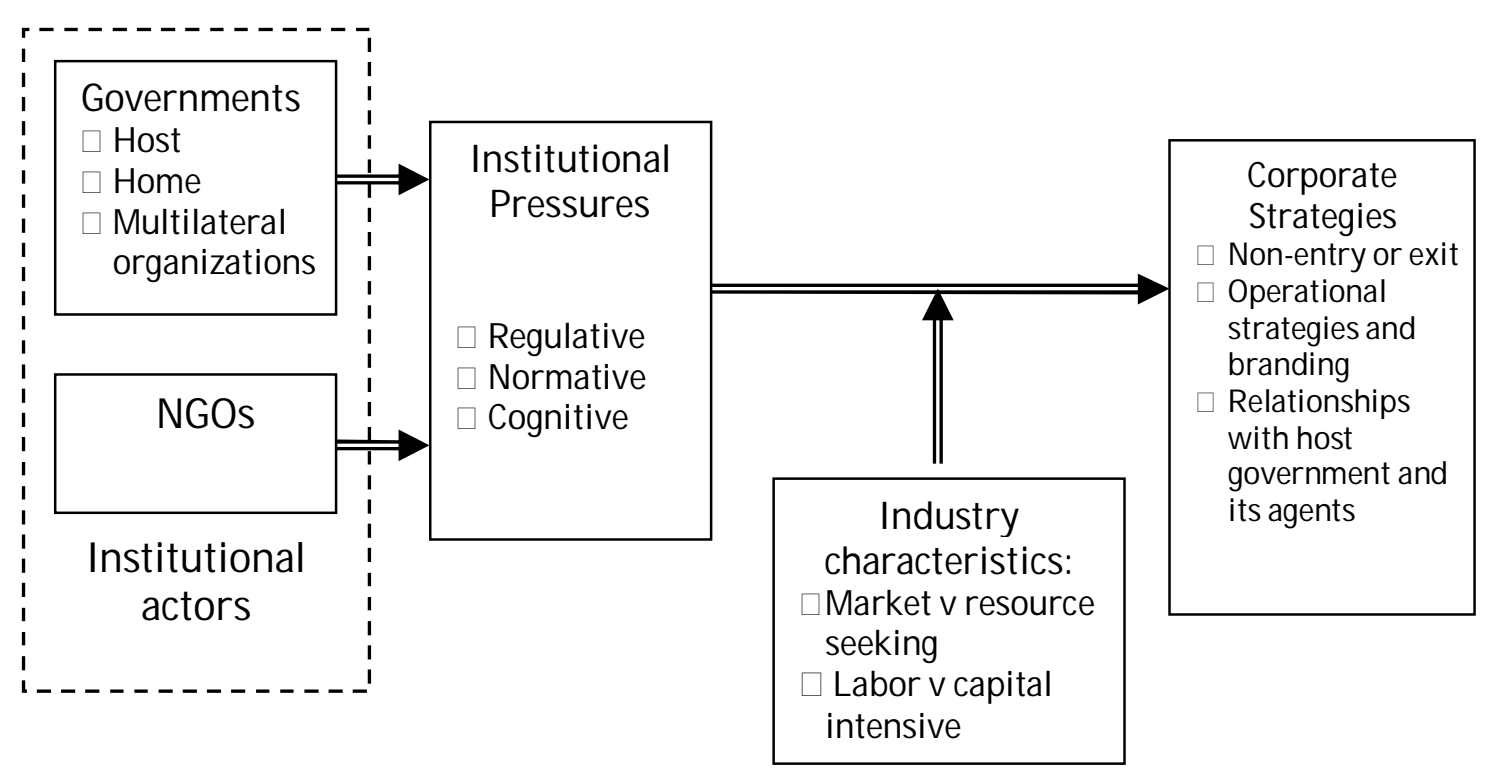


Figure 2: Study Design: Selection of Industries

\begin{tabular}{l|c|c|}
\multicolumn{1}{c}{ Capital Intensive } & \multicolumn{2}{c|}{ Capital Non-Intensive } \\
\cline { 2 - 3 } $\begin{array}{l}\text { Resource- } \\
\text { seeking }\end{array}$ & Oil and Gas & Garment manufacturing: \\
\cline { 2 - 3 } $\begin{array}{l}\text { Market- } \\
\text { seeking }\end{array}$ & Telecommunication & Consumer goods \\
\cline { 2 - 3 } & &
\end{tabular}


Figure 3: A Refined Theoretical Framework

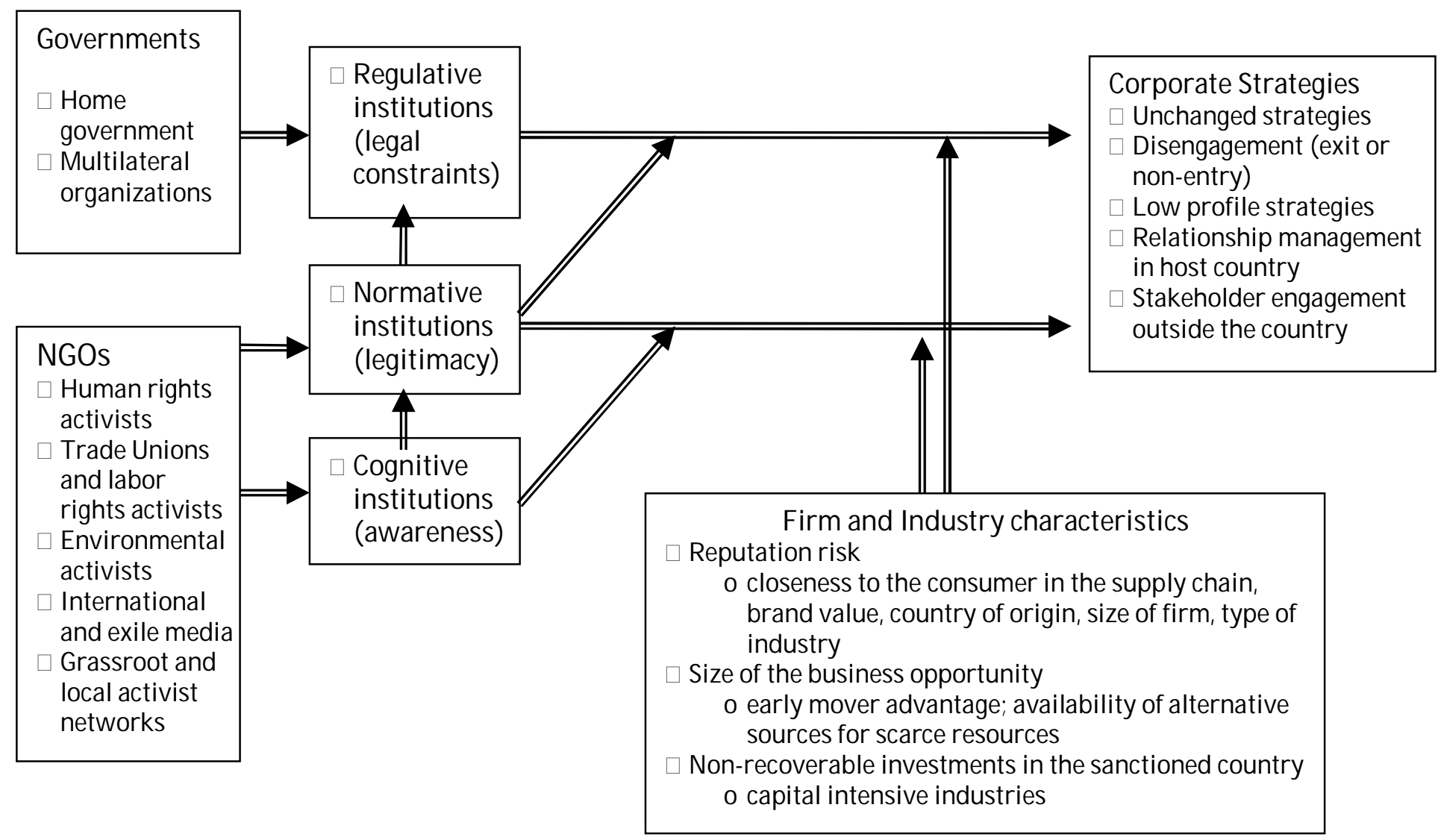

